\title{
Design, Synthesis and Biological Evaluation of Novel
}

\section{Carbohydrate-based Sulfamates as Carbonic}

\section{Anhydrase Inhibitors}

Marie Lopez ${ }^{\dagger}$, Jonathan Trajkovic ${ }^{\dagger}$, Laurent F. Bornaghi ${ }^{\dagger}$, Alessio Innocenti ${ }^{\S}$, Daniela Vullo ${ }^{\S}$, Claudiu T. Supuran ${ }^{\S, *}$ and Sally-Ann Poulsen ${ }^{\dagger, *}$

${ }^{\dagger}$ Eskitis Institute for Cell and Molecular Therapies, Griffith University, Nathan, Queensland 4111, Australia, §Polo Scientifico, Laboratorio di Chimica Bioinorganica, Rm. 188, Università degli Studi di Firenze, Via della Lastruccia 3, 50019 Sesto Fiorentino, Florence, Italy.

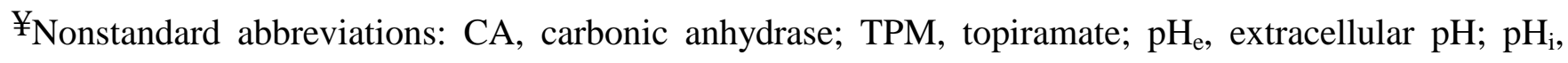
intracellular pH; c LogP, calculated Log P; TPSA, total polar surface area; LE, ligand efficiency; SAR, structure-activity relationship; SPR, structure-property relationship.

RECEIVED DATE (to be automatically inserted after your manuscript is accepted if required according to the journal that you are submitting your paper to)

Corresponding authors. (S-AP) Tel: +61-7-3735-7825; Fax: +61-7-3735-7656; e-mail:

s.poulsen@griffith.edu.au. $\quad$ (CTS) Tel: +39-055-4573005; Fax: +39-055-4573385; e-mail: claudiu.supuran@unifi.it. 


\section{Abstract}

Carbonic anhydrases (CAs) IX and XII are enzymes with newly validated potential for the development of personalized, first-in-class cancer chemotherapies. Here we present the design and synthesis of novel carbohydrate-based CA inhibitors, several of which were very efficient inhibitors $\left(K_{\mathrm{i}} \mathrm{s}<10 \mathrm{nM}\right)$ with good selectivity for cancer-associated CA isozymes over off-target CA isozymes. All inhibitors comprised a carbohydrate core with one hydroxyl group derivatized as a sulfamate. Five different carbohydrates were chosen to present a selection of molecular shapes with subtle stereochemical differences to the CA enzymes active site. Variable modifications of the remaining sugar hydroxyl groups were incorporated to provide an incremental coverage of chemical property parameters that are associated with biopharmaceutical performance. All sulfamate inhibitors displayed ligand efficiencies that are consistent with those reported for good drug lead candidates.

Keywords carbonic anhydrase, carbohydrate, sulfamate, topiramate, inhibitor, zinc binding group, cancer, prodrug 


\section{Introduction}

Carbonic anhydrases (CAs, EC 4.2.1.1) are zinc metalloenzymes that catalyze the reversible hydration of carbon dioxide $\left(\mathrm{CO}_{2}\right)$ to generate bicarbonate anion $\left(\mathrm{HCO}_{3}{ }^{-}\right)$and a proton $\left(\mathrm{H}^{+}\right)$, Scheme 1. ${ }^{1,2}$

Scheme 1. Endogenous reaction catalyzed by carbonic anhydrases.

$$
\mathrm{CO}_{2}+\mathrm{H}_{2} \mathrm{O} \leftrightarrows \mathrm{HCO}_{3}^{-}+\mathrm{H}^{+}
$$

This equilibrium contributes to a range of physiological functions that involve the production, transport or consumption of $\mathrm{CO}_{2}, \mathrm{H}^{+}$and $\mathrm{HCO}_{3}{ }^{-1} \cdot \mathrm{CA}$ isozymes IX and XII, are transmembrane enzymes with an extracellularly oriented active site. They are predominantly expressed in poorly vascularized hypoxic tumors and have minimal expression in healthy cells. ${ }^{3}$ Tumor cells experience elevated metabolism, and thus increased acid production, compared to healthy cells. ${ }^{3-6}$ If this acid-load is allowed to accumulate then intracellular $\mathrm{pH}\left(\mathrm{pH}_{\mathrm{i}}\right)$ would fall and disrupt critical biological functions. Recent evidence has demonstrated that cell-generated $\mathrm{CO}_{2}$, in addition to lactic acid, is predominantly responsible for the removal of excess acid from tumor cells. ${ }^{4} \mathrm{CO}_{2}$ is freely membrane permeable and rapidly exits metabolically active tumor cells via passive diffusion. ${ }^{5}$ The role of CA IX and XII is to catalyze the hydration of tumor generated $\mathrm{CO}_{2}$ to form $\mathrm{HCO}_{3}{ }^{-}$and $\mathrm{H}^{+}$(Scheme 1 ), the net effect is to trap $\mathrm{H}^{+}$extracellularly, lowering extracellular $\mathrm{pH}\left(\mathrm{pH}_{\mathrm{e}}\right)$ whilst maintaining normal $\mathrm{pH}_{\mathrm{i}}{ }^{3-5}$ This process favours tumor growth and invasion, allowing hypoxic tumor cells to survive and proliferate. ${ }^{4,7}$

The importance of modulating $\mathrm{pH}$ in the hypoxic tumor microenvironment underpins a strong case to develop well designed small-molecule inhibitors of CA IX and XII for application as chemical probes. These compounds are needed to appraise the potential of cancer-associated CAs as a possible mode for therapeutic intervention in cancer. ${ }^{1,8}$ The extracellular active site location of CA IX and XII together with their expression in hypoxic cancer cells (overexpression) compared to healthy cells (minimal expression) improves the odds for the development of tumor selective CA inhibitors. 
The implied target for small molecule drug design of CA inhibitors is the CA active site $\mathrm{Zn}^{2+}$ cation, and both sulfonamide $\left(-\mathrm{SO}_{2} \mathrm{NH}_{2}\right)$, and less frequently, sulfamate $\left(-\mathrm{OSO}_{2} \mathrm{NH}_{2}\right)$ zinc binding groups feature in the structure of many small molecule CA inhibitors. ${ }^{1,9}$ In the last few years our group has established a novel approach to targetting the inhibition of CA IX and XII using carbohydrate-based small molecules. ${ }^{10-15}$ Drug-like carbohydrate-based molecules are now viewed as a vast but relatively untapped source of potential new therapeutics. ${ }^{16,17}$ We have demonstrated that through appending sugar moieties to the $\mathrm{Ar}-\mathrm{SO}_{2} \mathrm{NH}_{2}$ zinc binding pharmacophore of classical CA inhibitors we were able to deliver potent inhibitors for CA IX and XII in vitro. ${ }^{18}$ More recently we reported a new class of compound that incorporates a sulfonamide moiety directly attached to the anomeric centre of a mono- or disaccharide i.e. [sugar]- $\mathrm{SO}_{2} \mathrm{NH}_{2} \cdot{ }^{19}$ The value of these anomeric sulfonamides was three-fold - first they were novel chemical entities, second they lacked the classical aromatic component of classical CA inhibitors, and third, they allowed us to tune the physicochemical properties of the inhibitor towards selective inhibition of CA IX and XII owing to the glycoconjugates compromised ability to diffuse across cell membranes. The CA inhibition activity of these compounds was however only moderate with $K_{\mathrm{i}} \mathrm{S}$ in the micromolar range. In the present contribution we extend our focus on modulating structureproperty relationships (SPR) of CA inhibitors whilst delivering novel compounds with good CA inhibition activity and isozyme selectivity. Specifically we present the design, synthesis and biological evaluation of carbohydrate-based sulfamates of the motif [sugar]- $\mathrm{OSO}_{2} \mathrm{NH}_{2}$.

\section{Results and Discussion}

Compound Design. Topiramate (2,3:4,5-bis-O-(l-methylethy1idene)-6-D-fructopyranosyl sulfamate, TPM) is a billion dollar drug that is marketed worldwide for the treatment of epilepsy and migraine. ${ }^{20}$ TPM is a fructose sulfamate and is an excellent inhibitor of CAs in vitro. ${ }^{21}$ The chemical structure of TPM has two isopropylidine groups masking four secondary hydroxyl groups, with the primary hydroxyl group sulfamoylated, Figure 1. 


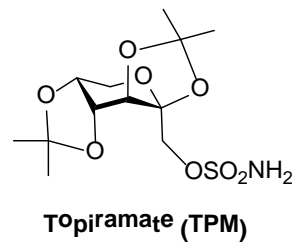

Figure 1. Structure of topiramate, a fructose sulfamate CA inhibitor.

The sulfamate compounds 7-18 of this study were derived from the monosaccharides D-glucose, Dgalactose, D-mannose and methyl $\alpha$-glucopyranoside and the disaccharide maltose, Figure 2a. The sulfamate group is on the C-6 (or C-6' for maltose) primary hydroxyl group. Compounds $\mathbf{1 3}$ and $\mathbf{1 8}$ are O-methyl glycosides, while the remaining hydroxyls of compounds are either acylated (7-13) or fully deprotected to provide free sugars (14-18).

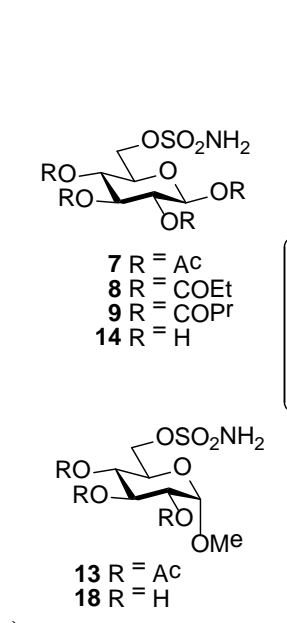

a)

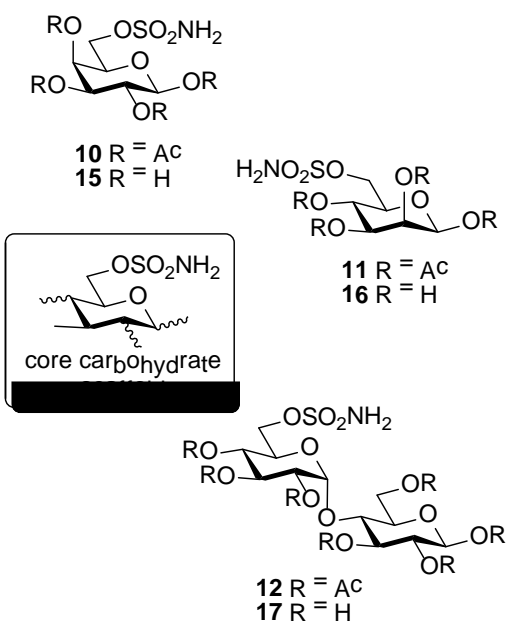

Figure 2. a) Target carbohydrate sulfamates. b) Overlay of stick models of sulfamates 7, 10, 12 and 13 . Common scaffold is coloured by atom type (red, grey, blue and yellow), variable acetate groups are coloured black.

In addition to inspiration from the impressive pharmaceutical pedigree of the carbohydrate-sulfamate drug TPM, the design principle towards the target molecules 7-18 was to develop a family of compounds that provided incremental coverage of chemical property space. The application of esters as a prodrug strategy to mask polar hydroxyl groups is prevalent across medicinal chemistry and chemical biology. ${ }^{22}$ Such prodrugs take advantage of hydrolysis by nonspecific esterases to unmask the hydroxyl 
groups in vivo, the prodrugs often survive the GI tract and may be absorbed into the blood stream where they are hydrolyzed by plasma enzymes. ${ }^{23}$ Esterification of the hydroxyl groups of carbohydrates has been used to modulate the membrane permeability and downstream activity of carbohydrate-based molecules. ${ }^{24,25}$ In this study we explore the acetyl, propionyl and butryl acyl groups, each are expected to be substrates of esterases. The five different sugar types of this study were chosen to present a selection of molecular shapes with subtle stereochemical differences to the CA enzyme active site and contribute to building valuable SAR. This is demonstrated by an overlay of stick models of sulfamates 7, 10, 12 and 13, Figure 2b. All compounds 7-18 preserve the sulfamate zinc binding group that is critical for good CA inhibition.

Chemical Synthesis. The carbohydrate sulfamate compounds 7-18 of this study were derived from commercially available monosaccharides D-glucose, D-galactose, D-mannose and methyl $\alpha$ glucopyranoside and the disaccharide maltose. The synthetic route to the monosaccharide sulfamates is presented in Schemes 2. The regioselective protection of the 6-position of the monosaccharides was achieved by reaction with trityl chloride in pyridine to introduce a trityl group, shown for D-glucose in Scheme $2 .^{26}$ The remaining secondary hydroxyl groups were then acylated with acetic anhydride, propionic anhydride or butyric anhydride to give compounds $1-3$, respectively. A mixture of $\alpha$ - and $\beta$ anomers was obtained with D-glucose, D-galactose and D-mannose, from which the $\beta$-anomer was either separated or carried through the detritylation step as a mixture of anomers, then separated. The $\alpha / \beta$ ratio was dependent both on the glycosyl residue and on the nature of the protecting group. The trityl ether protecting groups were removed with NaI/TMSCl to unmask the C-6 primary hydroxyl groups, providing precursor compounds 4-6. The yield for detritylation using this method is low compared to more traditional conditions, however these reagents avoid acyl group migration and the associated mixture of products. ${ }^{27,} 28$ Selective sulfamoylation of the now free C-6 hydroxyl groups of 4-6 with sulfamoyl chloride (generated in situ from formic acid and chlorosulfonylisocyanate) gave target sulfamates 7-9. ${ }^{29}$ Lastly, the $O$-acetate groups of the carbohydrate moiety of the sulfamates were 
removed using Zemplen's conditions ${ }^{30}$ to liberate the fully deprotected sugar analogue $\mathbf{1 4}$ as a mixture of anomers. Sulfamates $10, \mathbf{1 1}, \mathbf{1 3}, \mathbf{1 5}, \mathbf{1 6}$ and 18 were prepared similarly to Scheme 2.

Scheme 2. Synthetic route to target monosaccharide sulfamates, shown for D-glucose derivatives 7-9 and 14.

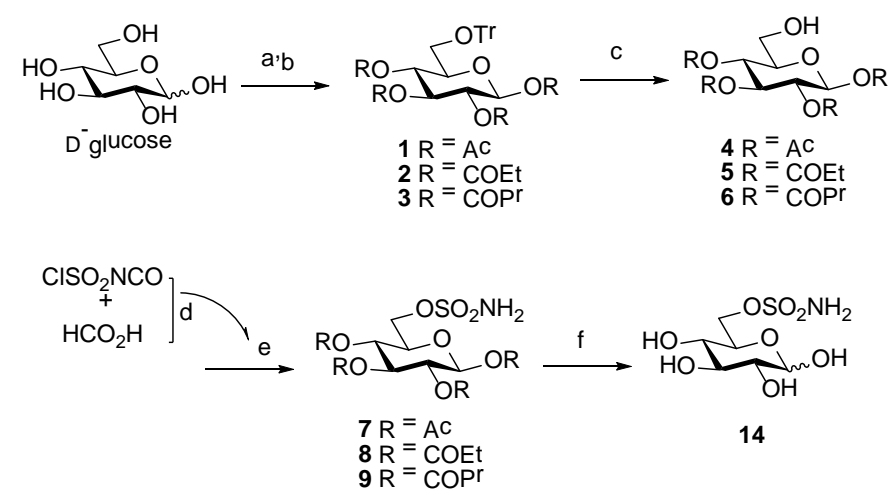

Reagents and Conditions: (a) $\mathrm{Ph}_{3} \mathrm{CCl}$, pyridine, $80{ }^{\circ} \mathrm{C}, 1.5 \mathrm{~h}$; (b) $\mathrm{R}_{2} \mathrm{O}, \mathrm{H}_{2} \mathrm{O}, 0{ }^{\circ} \mathrm{C}, 1 \mathrm{~h}$, yield over two steps 37-59\%. (c) TMSCl, NaI, $\mathrm{MeCN}, 0{ }^{\circ} \mathrm{C}$, then $\mathrm{Na}_{2} \mathrm{~S}_{2} \mathrm{O}_{3}, 19-57 \%$. (d) $\mathrm{HCO}_{2} \mathrm{H}, \mathrm{ClSO}_{2} \mathrm{NCO}, 0{ }^{\circ} \mathrm{C}-\mathrm{rt}$, 30 min; (e) $\mathrm{ClSO}_{2} \mathrm{NH}_{2}$ from (d), DMA, $0{ }^{\circ} \mathrm{C}-\mathrm{rt}$, $1 \mathrm{~h}$, yield over two steps $26-70 \%$. (f) compound 7, MeONa, $\mathrm{MeOH}$, rt, 1 h, 71\%.

The synthesis of the target maltose sulfamates $\mathbf{1 2}$ and $\mathbf{1 7}$ followed an analogous strategy to the monosaccharides, however several additional steps were needed to accommodate selectivity in the presence of the two primary alcohols of the disaccharide, Scheme 3. First the 4',6'-O-benzylidine acetal of maltose is prepared, and the remaining six hydroxyl groups acetylated. Removal of the benzylidene acetal with aqueous acetic acid provides a diol precursor that is manipulated similarly to the procedure outlined for the monosaccharides. All target sulfamates 7-18 were spectroscopically characterized using 1D and 2D NMR $\left({ }^{1} \mathrm{H},{ }^{13} \mathrm{C}\right.$, gCOSY, gHSQC). The characterization data were consistent with the target structures, with a characteristic broad singlet for the sulfamate protons $\left(\mathrm{O}-\mathrm{SO}_{2} \mathrm{NH}_{2}\right)$ for all compounds observed at $\delta$ 7.40-7.60 $\mathrm{ppm}$ in $d^{6}$-DMSO. 
Scheme 3. Synthetic route to target disaccharide sulfamates 12 and $\mathbf{1 7}$ starting from commercially available maltose.
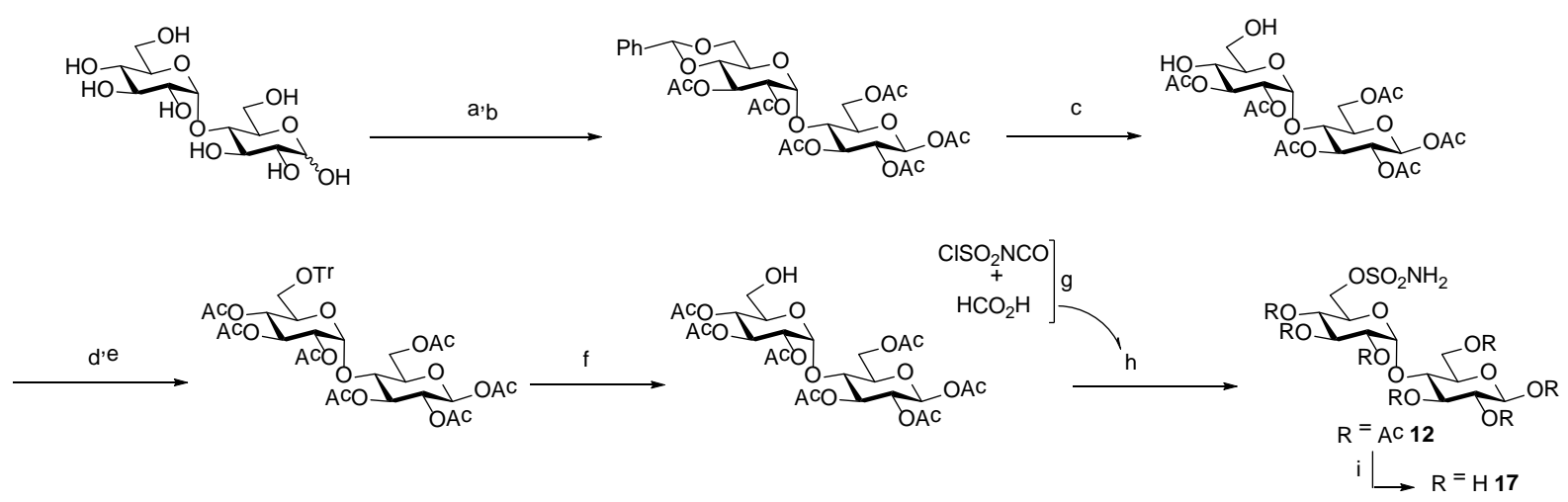

Reagents and Conditions: (a) $\alpha, \alpha^{\prime}$-dimethoxytoluene, $p$-TSA, DMF, $40{ }^{\circ} \mathrm{C}, 40 \mathrm{mbar}$; (b) $\mathrm{Ac}_{2} \mathrm{O}$, NaOAc, reflux, $0.5 \mathrm{~h}$, yield over 2 steps $72 \%$ ( $\beta$-anomer). (c) $80 \% \mathrm{AcOH}_{\mathrm{aq}}, \mathrm{rt}, 30 \mathrm{~min}, 46 \%$. (d) $\mathrm{Ph}_{3} \mathrm{CCl}$, pyridine, $80{ }^{\circ} \mathrm{C}, 1.5 \mathrm{~h}$; (e) $\mathrm{Ac}_{2} \mathrm{O}, \mathrm{H}_{2} \mathrm{O}, 0{ }^{\circ} \mathrm{C}, 1 \mathrm{~h}$, yield over two steps $81 \%$. (f) $\mathrm{TMSCl}, \mathrm{NaI}$, $\mathrm{MeCN}, 0{ }^{\circ} \mathrm{C}$, then $\mathrm{Na}_{2} \mathrm{~S}_{2} \mathrm{O}_{3}, 60 \%$. (g) $\mathrm{HCO}_{2} \mathrm{H}, \mathrm{ClSO}_{2} \mathrm{NCO}, 0{ }^{\circ} \mathrm{C}-\mathrm{rt}, 30 \mathrm{~min}$; (h) $\mathrm{ClSO}_{2} \mathrm{NH}_{2}$ from (g), DMA, $0{ }^{\circ} \mathrm{C}-\mathrm{rt}, 1 \mathrm{~h}$, yield over two steps 50\%. (i) MeONa, MeOH, rt, 1 h, 37\%.

Carbonic Anhydrase Inhibition. The enzyme inhibition data for sulfamates 7-18 as well as the sulfamate drug TPM were determined by assaying the CA catalyzed hydration of $\mathrm{CO}_{2}$, Table $1 .^{31}$ Enzyme inhibition data for the physiologically dominant CA I and II, and tumor-associated CA IX and XII were obtained. Isozyme selectivity ratios for 7-18 and TPM are also provided, Table 1.

Table 1. Inhibition and isozyme selectivity ratio data of hCA Isozymes I, II, IX and XII with sulfamates 7-18, and the carbohydrate sulfamate drug TPM. ( $\mathrm{h}=$ human)

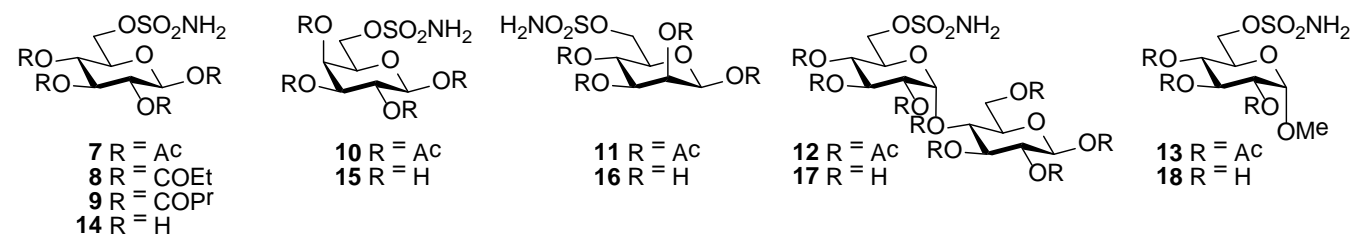

\begin{tabular}{l|l|l|l|l|l|l|l|l|}
\hline \multirow{2}{*}{ Compound } & \multicolumn{3}{|c|}{$K_{\text {i }}(\mathbf{n M})^{a}$} & \multicolumn{3}{c}{ Selectivity ratios $^{d}$} \\
\cline { 2 - 8 } & CA I I $^{b}$ & CA II $^{b}$ & CA IX $^{c}$ & CA XII $^{c}$ & I/IX & I/XII & II/IX & II/XII \\
\hline
\end{tabular}




\begin{tabular}{|c|c|c|c|c|c|c|c|c|}
\hline $\mathrm{TPM}^{\dagger}$ & 250 & 5.0 & 58 & 3.8 & 4.3 & 65.8 & 0.1 & 1.3 \\
\hline 7 & 4610 & 307 & 73 & 85 & 63.2 & 54.2 & 4.2 & 3.6 \\
\hline 8 & 3360 & 105 & 77 & 96 & 43.6 & 35.0 & 1.4 & 1.1 \\
\hline 9 & 5640 & 114 & 86 & 87 & 65.6 & 64.8 & 1.3 & 1.3 \\
\hline 10 & 860 & 106 & 75 & 9.5 & 11.5 & 90.5 & 1.4 & 11.2 \\
\hline 11 & 970 & 11.3 & 7.8 & 8.4 & 124.4 & 115.5 & 1.5 & 1.4 \\
\hline 12 & 12600 & 754 & 631 & 145 & 20.0 & 96.9 & 1.2 & 5.2 \\
\hline 13 & 5660 & 66 & 8.4 & 7.6 & 673.8 & 744.7 & 7.9 & 8.7 \\
\hline 14 & 1180 & 82 & 8.6 & 7.3 & 137.2 & 161.6 & 9.5 & 11.2 \\
\hline 15 & 4500 & 93 & 62 & 7.6 & 72.6 & 592.1 & 1.5 & 12.2 \\
\hline 16 & 5960 & 104 & 53 & 9.5 & 112.5 & 627.4 & 1.97 & 10.9 \\
\hline 17 & 8750 & 513 & 497 & 138 & 17.6 & 63.4 & 1.0 & 3.7 \\
\hline 18 & 1190 & 129 & 9.0 & 93 & 132.2 & 12.8 & 14.3 & 1.4 \\
\hline
\end{tabular}

${ }^{a}$ Errors in the range of $\pm 5-10 \%$ of the reported value, from three determinations. ${ }^{b}$ Human (cloned) isozymes. ${ }^{c}$ Catalytic domain of human (cloned) isozymes. ${ }^{d}$ These are $K_{\mathrm{i}}$ ratios and are indicative of isozyme selectivity in vitro. ${ }^{f}$ The values for TPM are consistent with previous reports. ${ }^{18}$

Off-target CA isozyme I. The sulfamate compounds were micromolar inhibitors of the off-target CA I isozyme, with $K_{\mathrm{i}} \mathrm{S}$ ranging from $0.86-12.6 \mu \mathrm{M}$. Inhibition at CA I is weaker than for the other CA isozymes. The TPM inhibition profile behaves similarly, also showing poorer inhibition of CA I $\left(K_{\mathrm{i}}=\right.$ $250 \mathrm{nM}$ ) than for the other CA isozymes. The structural variability provided by the three different acyl groups had no remarkable impact on structure-activity relationships (SAR) at CA I with the $K_{\mathrm{i}}$ values for 
acetyl $7\left(K_{\mathrm{i}}=4.6 \mu \mathrm{M}\right)$, propionyl $8\left(K_{\mathrm{i}}=3.4 \mu \mathrm{M}\right)$ or butryl $9\left(K_{\mathrm{i}}=5.6 \mu \mathrm{M}\right)$ glucose sulfamates similar. Notable however was that the free sugar glucose analogue 14 was a better CA I inhibitor $\left(K_{\mathrm{i}}=1.2 \mu \mathrm{M}\right)$ than the acylated analogues 7-9. The disaccharide maltose derivatives $12\left(K_{\mathrm{i}}=12.6 \mu \mathrm{M}\right)$ and $\mathbf{1 7}\left(K_{\mathrm{i}}=\right.$ $8.74 \mu \mathrm{M}$ ) were weaker inhibitors than the monosaccharides.

Off-target CA isozyme II. CA II is a much more efficient enzyme than CA I and inhibition of this isozyme is largely responsible for side effects associated with clinically used CA inhibitors. ${ }^{1}$ TPM is a very potent CA II inhibitor with a $K_{\mathrm{i}}$ of $5.0 \mathrm{nM}$. Compound 11, the acetylated mannose derivative, was the only potent CA II inhibitor of the novel sulfamates $\left(K_{\mathrm{i}}=11.3 \mathrm{nM}\right)$. The remaining monosaccharide sulfamates were moderately active at this off-target enzyme, with $K_{\mathrm{i}}$ s ranging from 66 - $307 \mathrm{nM}$. Given the sole structural difference between compound $\mathbf{1 1}$ and compounds $\mathbf{7}$ and $\mathbf{1 0}$ is the stereochemistry of one position on the monosaccharide moiety this is intriguing SAR that may assist to identify further opportunities in CA inhibitor design. As for CA I, the maltose derivatives $12\left(K_{\mathrm{i}}=754 \mathrm{nM}\right)$ and $17\left(K_{\mathrm{i}}=\right.$ $513 \mathrm{nM}$ ) were the weakest inhibitors at CA II, while the three different acyl groups of 7-9 also had little impact on SAR at CA II.

Cancer-associated CA isozymes IX and XII. Sulfamates 11, 13, 14 and 18 were good CA IX inhibitors with inhibition constants clustered below $10 \mathrm{nM}\left(K_{\mathrm{i}} \mathrm{s} 7.9-9.0 \mathrm{nM}\right)$ with very good selectivity over the off-target CA I (124- to 674-fold) and up to 14-fold selectivity against CA II, the latter is very good and contrasts with the behaviour of TPM which is non-selective for CA II. At hCA IX compounds 7-10, 15 and 16 had $K_{\mathrm{i}}$ s ranging from 53-86 nM similar to TPM ( $K_{\mathrm{i}}$ of $\left.58 \mathrm{nM}\right)$. These compounds generally had good selectivity over CA I (up to 112-fold) but were non-selective over CA II. At CA XII sulfamates were generally more effective inhibitors than for other isozymes, with $K_{\mathrm{i}} \mathrm{s}$ for compounds $\mathbf{1 3 - 1 6}$ ranging from 7.3 - $9.5 \mathrm{nM}$, compared to TPM with a $K_{\mathrm{i}}$ of $3.8 \mathrm{nM}$. Compounds 10, 14-16 had >10-fold selectivity over CA II and >70-fold selectivity over CA I. With the exception of 14, these compounds 
were also selective over CA IX (5.6 to 8.2-fold), a property that is likely to prove valuable for applications as chemical probes. Compounds 7-9 and 18 were moderate CA XII inhibitors with $K_{\mathrm{i}} \mathrm{s}$ ranging from 85 - $96 \mathrm{nM}$. These compounds had good selectivity over CA I, but were non-selective compared to CA II inhibition.

Comparison with anomeric sulfonamides. Recently we reported the CA inhibition properties of Sglycosyl primary sulfonamides. ${ }^{19}, 32$ These were a new class of compound wherein a primary sulfonamide moiety was directly bonded to a sterochemically rich carbohydrate scaffold, notably without an intervening aromatic moiety. The enzyme inhibition data and isozyme selectivity ratios for glucose, galactose and maltose anomeric sulfonamides 19-24 at CA I, II, IX and XII are provided in Table 2. When comparing the anomeric sulfonamides 19-24 with their corresponding sulfamates $\mathbf{7}, \mathbf{1 4}$, 10, 15, 12 and 17 it is readily apparent that the sulfamates are far superior CA inhibitors at CA II, IX and XII, while both groups of compounds are weak CA I inhibitors. As well, the anomeric sulfonamides showed no isozyme selectivity, while the reverse is true for the C-6 sulfamates, some of which display excellent selectivity for the cancer-associated CAs. Using protein X-ray crystallography we demonstrated that the shape of the anomeric sulfonamide ligands resulted in less than optimal CA active site interactions. ${ }^{19}$ The design of the new compounds of this study address this limitation and has provided better performing compounds.

Table 2. Inhibition and isozyme selectivity ratio data of hCA Isozymes I, II, IX and XII with anomeric sulfonamides $19-24 .^{19}(\mathrm{~h}=$ human$)$

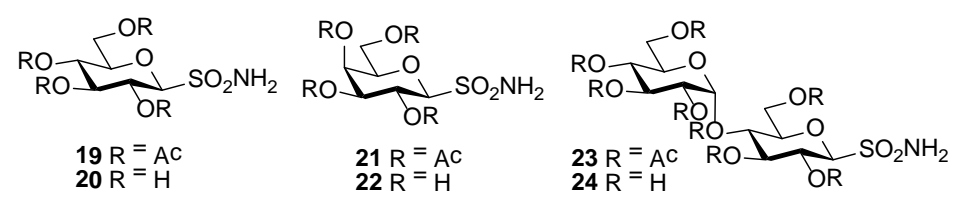

\begin{tabular}{c|c|c}
\hline Compound & $K_{\mathrm{i}}(\mathrm{nM})^{a}$ & Selectivity ratios $^{d}$ \\
\hline
\end{tabular}




\begin{tabular}{|c|c|c|c|c|c|c|c|c|}
\hline & $\mathrm{CA} \mathrm{I}^{b}$ & $\mathrm{CA} \mathrm{II}^{b}$ & $\mathrm{CA} \mathrm{IX}^{c}$ & $\mathrm{CA} \mathrm{XII}^{\mathrm{C}}$ & I/IX & $\mathrm{I} / \mathrm{XII}$ & II/IX & $\mathrm{II} / \mathrm{XII}$ \\
\hline 19 & 4530 & 4500 & 3910 & 4660 & 1.15 & 0.97 & 1.15 & 0.97 \\
\hline 20 & 3900 & 4910 & 4050 & 4690 & 0.96 & 0.83 & 1.21 & 1.05 \\
\hline 21 & 4340 & 4350 & 4150 & 4710 & 1.05 & 0.92 & 1.05 & 0.92 \\
\hline 22 & 3710 & 4550 & 4190 & 4800 & 0.89 & 0.77 & 1.09 & 0.95 \\
\hline 23 & 4120 & 4980 & 4080 & 4610 & 1.01 & 0.89 & 1.22 & 1.08 \\
\hline 24 & 4150 & 4100 & 4220 & 4840 & 0.98 & 0.86 & 0.97 & 0.85 \\
\hline
\end{tabular}

\footnotetext{
${ }^{a}$ Errors in the range of $\pm 5-10 \%$ of the reported value, from three determinations. ${ }^{b}$ Human (cloned) isozymes. ${ }^{c}$ Catalytic domain of human (cloned) isozymes. ${ }^{d}$ These are $K_{\mathrm{i}}$ ratios and are indicative of isozyme selectivity in vitro.
}

Structure-Property Relationships (SPR). The incorporation of variable acyl protecting groups onto the carbohydrate core of glucose derivatives 7-9, 13, 14 and 18 has encapsulated a range of LogP and topological polar surface area (TPSA) values, Table 3. Manipulating these physicochemical parameters is a useful way to refine druggability and notably this coverage of chemical property space was achieved with retention of the underlying glucose sulfamate core. ${ }^{33,34}$ Values for TPSA, calculated LogP (cLogP), molecular weight (MW) and ligand efficiency (LE) for TPM and all glucose sulfamates are provided in Table 3. TPSA is a descriptor for characterising lipid membrane barrier diffusion. Molecules with a TPSA >140 $\AA^{2}$ are likely to have a low capacity for penetrating cell membranes, while those with TPSA $\leq 60 \AA^{2}$ typically have good passive permeability properties. ${ }^{35,}{ }^{36}$ For the glucose sulfamates the calculated TPSA values ranged from $160-184 \AA^{2}$ which is above the upper limit $\left(140 \AA^{2}\right)$ for good passive permeability properties. cLog $\mathrm{P}$ values $<0$ are indicative of molecules with poor membrane permeability. The cLogP values are consistent with the compound design and provide a broad range that extends from -3.3 for compound 14 (four free hydroxyl groups) to +3.52 for compound $\mathbf{9}$ (four butyryl 
protected hydroxyl groups), this again is noteworthy given that the underlying active core structure is retained. The per-O-acetylated compounds 7 and 13, despite no free hydroxyl groups still have cLog P values $<0$ (values of -0.72 and -0.79 , respectively), while the propionyl and butyryl protected compounds 8 and 9 have cLog $\mathrm{P}$ values of +1.40 and +3.52 , respectively. The implications of these values may prove useful for the provision of compounds suited for oral administration. Compounds 8 and $\mathbf{9}$ are predicted to be orally bioavailable, yet once absorbed their physicochemical properties altered by esterase activity to give a more polar molecule (compound 14) that as a consequence selectively targets the extracellular active site of cancer-associated CAs.

LE represents the relationship between a compounds potency and its MW and is now emerging as an important metric to guide drug discovery campaigns. The LE value is indicative of the prospects for druggability properties such as bioavailability, stability and solubility and permits the comparison of the relative quality of different leads. ${ }^{37}$ Perola recently reported an analysis of 60 lead/drug pairs, ${ }^{38}$ the findings from this analysis revealed a number of useful threshold values to guide medicinal chemists, notably that $90 \%$ of drug leads had LE $>12.4$, while $90 \%$ of drugs had LE $>14.7$. All sulfamates of this study have LE similar to, or far exceeding these thresholds at the cancer-associated CAs, Table 3. Compound 14, a free sugar, represents the core scaffold of all the novel sulfamates of this study and has the highest LE (>30) at both CA IX and CA XII. The other free sugar of this study, compound 18 was also a very efficient ligand, with LE $>20$ at both CA IX and CA XII. The precursors to 14, compounds 8 and 9, have LE values > 14 and >13, respectively, indicative of good drug leads and supporting our strategy with masking the hydroxyl groups.

Table 3. Calculated properties for TPM and glucose sulfamate derivatives 7-9, 13, 14 and 18.

\begin{tabular}{llllll}
\hline Compound & $\operatorname{cLogP}^{\mathbf{a}}$ & TPSA $_{\left(\AA^{2}\right)^{\mathbf{b}}}$ & MW (Da) & LE $_{(\text {CA IX) }}{ }^{\mathbf{c}}$ & LE $_{(\text {CA XII) }}{ }^{\mathbf{c}}$ \\
\hline TPM & +0.04 & 116 & 339.4 & 21.3 & 24.8
\end{tabular}




$\begin{array}{lrrrrr}\mathbf{7} & -0.72 & 184 & 427.4 & 16.7 & 16.6 \\ \mathbf{8} & +1.40 & 184 & 483.5 & 14.7 & 14.5 \\ \mathbf{9} & +3.52 & 184 & 539.6 & 13.1 & 13.1 \\ \mathbf{1 3} & -0.79 & 167 & 399.4 & 17.9 & 20.4 \\ \mathbf{1 4} & -3.30 & 160 & 259.2 & 31.1 & 31.4 \\ \mathbf{1 8} & -2.67 & 149 & 273.3 & 20.2 & 20.3\end{array}$

\footnotetext{
${ }^{a}$ CLog P data calculated using InstantJChem 3.0.4 from ChemAxon. ${ }^{b}$ TPSA calculated using ChemBioDraw Ultra 11.0. ${ }^{c} \mathrm{LE}$ calculated using equation $\mathrm{LE}=\mathrm{pK}_{i} / \mathrm{MW}(\mathrm{MW}$ in $\mathrm{KDa}) .{ }^{38}$
}

\section{Conclusions}

In summary, our study has delivered novel, potent and selective carbohydrate-based sulfamates that inhibit cancer-associated CAs. Compounds comprised a sulfamate zinc binding group appended to the C-6 hydroxyl of a panel monosaccharides or the C-6' hydroxyl of maltose. The SAR and SPR properties for these compounds, with variable acyl protecting groups, has provided a new approach to CA inhibitor development. Parent sulfamates are predicted to have good oral bioavailability, yet target selectively the active site of extracellular CA IX and XII over intracellular CAs once processed by esterases. Collectively this library of carbohydrate-based sulfamates exhibits biopharmaceutical properties that render these compounds potentially valuable for applications as chemical probes in medicinal chemistry.

\section{Experimental Section}

Chemistry. All starting materials and reagents were purchased from commercial suppliers. Solvents were dried prior to use, or purchased anhydrous from Sigma-Aldrich. All reactions were monitored by TLC using Merck $\mathrm{F}_{20}{ }_{254}$ silica plates with visualization of product bands by UV fluorescence $(\lambda=254$ $\mathrm{nm})$ and charring with orcinol stain ( $1 \mathrm{~g}$ of orcinol monohydrate in a mixture of $\mathrm{EtOH}: \mathrm{H}_{2} \mathrm{O}: \mathrm{H}_{2} \mathrm{SO}_{4}$ 
72.5:22.5:5). Silica gel flash chromatography was performed using silica gel (Davisil) $60 \AA$ (230-400 mesh). NMR $\left({ }^{1} \mathrm{H},{ }^{13} \mathrm{C}\left\{{ }^{1} \mathrm{H}\right\}\right.$, gCOSY and HSQC) spectra were recorded on a Varian $500 \mathrm{MHz}$ spectrometer at $30{ }^{\circ} \mathrm{C}$. For ${ }^{1} \mathrm{H}$ and ${ }^{13} \mathrm{C}$ NMR acquired in $\mathrm{CDCl}_{3}$ chemical shifts $(\delta)$ are reported in ppm relative to the solvent residual peak: proton $(\delta=7.27 \mathrm{ppm})$ and carbon $(\delta=77.2 \mathrm{ppm})$, respectively. Chemical shifts for ${ }^{1} \mathrm{H}$ and ${ }^{13} \mathrm{C}$ NMR acquired in DMSO- $d_{6}$ are reported in ppm relative to residual solvent proton $(\delta=2.50 \mathrm{ppm})$ and carbon $(\delta=39.5 \mathrm{ppm})$ signals, respectively. Multiplicity is indicated as follows: s (singlet); d (doublet); t (triplet); m (multiplet); dd (doublet of doublet); ddd (doublet of doublet of doublet); br s (broad singlet). Coupling constants are reported in hertz (Hz). Melting points measured on a Cole Parmer instrument are reported uncorrected. Low resolution mass spectra were acquired on an Applied Biosystems Pty Ltd Mariner ESI-TOF mass spectrometer using electrospray as the ionization technique in positive ion and/or negative ion modes as stated. High resolution mass spectra were performed in positive ion mode on an Apex III Bruker Daltonics 4.7T Fourier Transform mass spectrometer fitted with an Apollo electrospray ionization source. All MS analysis samples were prepared as solutions in methanol. Optical rotations were measured on a Jasco P-1020 polarimeter at 25 ${ }^{\circ} \mathrm{C}$ with Na-589 nm wave length and a $100 \mathrm{~mm}$ cell and reported as an average of ten measurements. The purities of isolated products were determined by HPLC obtained on an LCMS instrument (MS-ZQ Waters; HPLC-Alliance Waters) using a HPLC column (Ascentis, C18 $3 \mu \mathrm{m}, 5 \mathrm{~cm}$ x $4.6 \mathrm{~mm}$ ). Elution was performed with a gradient of water:methanol (containing $1 \%$ formic acid) from 95:5 to 0:100 for $10 \mathrm{~min}$ at a flow rate of $1 \mathrm{~mL} / \mathrm{min}$. UV (200 to $400 \mathrm{~nm}$ ) and ELSD (Evaporative Light Scattering Detection-Alltech) detection were used. Purity of all compounds proved to be $\geq 95 \%$. The synthesis of all intermediates was adapted from literature methods and is described in Supporting Information.

General procedure 1 - synthesis of sulfamates $7-13 .^{29}, 39$ The carbohydrate precursor (1.0 equiv.) was dried under vacuum and solubilized in anhydrous $N, N$-dimethyl acetamide (15 equiv.) under argon. Sulfamoyl chloride (3.8 equiv.) was prepared from formic acid and chlorosufonyl isocyanate at $0{ }^{\circ} \mathrm{C}$ in a dry two-neck flask connected to a bubbler and under an anhydrous atmosphere of argon. The alcohol 
solution was added slowly to the flask containing sulfamoyl chloride, then the reaction was allowed to warm to rt and stirred under argon for $1 \mathrm{~h}$. The crude reaction mixture was diluted in EtOAc, washed with $\mathrm{H}_{2} \mathrm{O}(\times 1)$ and brine $(\times 2)$. The aqueous fractions were back extracted with EtOAc $(\times 2)$, then the organic fractions combined, dried over $\mathrm{MgSO}_{4}$, filtered and concentrated.

1,2,3,4-Tetra-O-acetyl-6-sulfamoyl- $\boldsymbol{\beta}$-D-glucopyranose (7). The title compound 7 was prepared from 1,2,3,4-tetra- $O$-acetyl- $\beta$-D-glucopyranose according to general procedure 1 . Recrystallization of the crude product from EtOH afforded 7 (67\% yield) as white crystals. m.p. $=126^{\circ} \mathrm{C} .[\alpha]^{25}{ }_{\mathrm{D}}=+8(c=1.0$, chloroform). $\mathrm{R}_{f}=0.58$ (3:1 EtOAc/hexane). ${ }^{1} \mathrm{H}$ NMR (500 MHz, DMSO-d $\left.{ }_{6}\right): \delta=7.56\left(\mathrm{~s}, 2 \mathrm{H}, \mathrm{NH}_{2}\right)$; 5.98 (d, $J=8.5 \mathrm{~Hz}, 1 \mathrm{H}, \mathrm{H}-1) ; 5.44$ (t, $J=9.5 \mathrm{~Hz}, 1 \mathrm{H}, \mathrm{H}-3) ; 4.95$ (t, $J=10.0 \mathrm{~Hz}, 1 \mathrm{H}, \mathrm{H}-2) ; 4.94$ (t, $J=$ $9.5 \mathrm{~Hz}, 1 \mathrm{H}, \mathrm{H}-4$ ); 4.28 (ddd, $J$ = 8.5, 5.5, $2.5 \mathrm{~Hz}, 1 \mathrm{H}, \mathrm{H}-5$ ); 4.04 (dd, $J=11.5,2.5 \mathrm{~Hz}, 1 \mathrm{H}, \mathrm{H}-6 \mathrm{a}$ ); 4.00 (dd, $J=11.5,5.5 \mathrm{~Hz}, 1 \mathrm{H}, \mathrm{H}-6 \mathrm{~b}) ; 2.07,2.01,2.00,1.94\left(4 \times \mathrm{s}, 12 \mathrm{H}, \mathrm{OCOCH}_{3}\right)$, assignments were confirmed by ${ }^{1} \mathrm{H}-{ }^{1} \mathrm{H}$ gCOSY. ${ }^{13} \mathrm{C}$ NMR $\left(125 \mathrm{MHz}\right.$, DMSO- $\left.\mathrm{d}_{6}\right): \delta=169.5,169.2,169.1,168.7(4 \times$ OCOCH 3 ); 90.8 (C-1); 71.8 (C-3); 71.4 (C-5); 70.7 (C-4); 67.8 (C-2); 66.6 (C-6); 20.5, 20.4, 20.3, 20.3 $\left(4 \times \mathrm{OCOCH}_{3}\right)$, assignments were confirmed by ${ }^{1} \mathrm{H}^{13}{ }^{13} \mathrm{C}$ HSQC. LRMS $\left(\mathrm{ESI}^{+}\right): \mathrm{m} / \mathrm{z}=450[\mathrm{M}+\mathrm{Na}]^{+}$. HRMS: Calcd for $\mathrm{C}_{14} \mathrm{H}_{21} \mathrm{NO}_{12} \mathrm{SNa}^{+} 450.0677$, Found 450.0657 .

1,2,3,4-Tetra-O-propionyl-6-sulfamoyl- $\boldsymbol{\beta}$-D-glucopyranose (8). The title compound $\mathbf{8}$ was prepared from 1,2,3,4-tetra-O-propionyl- $\beta$-D-glucopyranose according to general procedure 1 . Purification of the crude product by flash chromatography (2:3 EtOAc/hexane) afforded 8 (70\% yield) as a white solid. m.p. $=119^{\circ} \mathrm{C} .[\alpha]^{25}=+11(c=1.0$, chloroform $) . \mathrm{R}_{f}=0.21\left(1: 2 \mathrm{EtOAc/hexane)} .{ }^{1} \mathrm{H}\right.$ NMR (500 MHz, DMSO- $\left.d_{6}\right): \delta=7.55$ (s, 2H, NH $\left.H_{2}\right) ; 6.02$ (d, $\left.J=8.5 \mathrm{~Hz}, 1 \mathrm{H}, \mathrm{H}-1\right) ; 5.48$ (t, $\left.J=9.5 \mathrm{~Hz}, 1 \mathrm{H}, \mathrm{H}-3\right) ; 4.98$ (t, $J$ $=10.0 \mathrm{~Hz}, 1 \mathrm{H}, \mathrm{H}-2) ; 4.97$ (t, $J=9.5 \mathrm{~Hz}, 1 \mathrm{H}, \mathrm{H}-4) ; 4.31$ (ddd, $J=9.5,5.0,2.5 \mathrm{~Hz}, 1 \mathrm{H}, \mathrm{H}-5$ ); 4.03 (dd, $J$ = 11.0, $2.5 \mathrm{~Hz}, 1 \mathrm{H}, \mathrm{H}-6 \mathrm{a}) ; 4.00$ (dd, $J=11.0,5.5 \mathrm{~Hz}, 1 \mathrm{H}, \mathrm{H}-6 \mathrm{~b}) ; 2.36,2.29,2.25,2.19(4 \times \mathrm{m}, 8 \mathrm{H}$, $\left.\mathrm{OCOCH}_{2} \mathrm{CH}_{3}\right) ; 1.01,1.00,0.98,0.96\left(4 \times\right.$ br t, $\left.J=7.5 \mathrm{~Hz}, 12 \mathrm{H}, \mathrm{OCOCH}_{2} \mathrm{CH}_{3}\right)$, assignments were 
confirmed by ${ }^{1} \mathrm{H}-{ }^{1} \mathrm{H}$ gCOSY. ${ }^{13} \mathrm{C}$ NMR $\left(125 \mathrm{MHz}\right.$, DMSO- $\left.d_{6}\right): \delta=169.5,169.2,169.1,168.7(4 \times$ OCOEt); 91.2 (C-1); 72.1 (C-3); 71.9 (C-5); 70.4 (C-4); 68.2 (C-2); 67.1 (C-6); 27.2, 27.2, 27.1, 27.1 (4 $\left.\times \mathrm{OCOCH}_{2} \mathrm{CH}_{3}\right)$; 9.5, 9.4, 9.3, $9.0\left(4 \times \mathrm{OCOCH}_{2} \mathrm{CH}_{3}\right)$, assignments were confirmed by ${ }^{1} \mathrm{H}^{13}{ }^{13} \mathrm{C} \mathrm{HSQC}$. LRMS $\left(\mathrm{ESI}^{+}\right): \mathrm{m} / \mathrm{z}=506[\mathrm{M}+\mathrm{Na}]^{+}$. HRMS: Calcd for $\mathrm{C}_{18} \mathrm{H}_{29} \mathrm{~N}_{1} \mathrm{O}_{12} \mathrm{SNa}^{+}$506.1303, Found 506.1290.

\section{1,2,3,4-Tetra-O-butyryl-6-sulfamoyl- $\boldsymbol{\beta}$-D-glucopyranose (9). The title compound $\mathbf{9}$ was prepared} from 1,2,3,4-tetra-O-butyryl- $\beta$-D-glucopyranose according to general procedure 1 . Purification of the crude product (1:9 acetone/toluene) afforded the title compound as a mixture of $\alpha$ - and $\beta$-anomers. A further recrystallization from EtOH afforded the $\beta$-anomer 9 (26\% yield) as white crystals. m.p. $=109$ ${ }^{\circ} \mathrm{C} .[\alpha]^{25}=+9\left(c=1.0\right.$, chloroform). $\mathrm{R}_{f}=0.25$ (1:9 acetone/toluene). ${ }^{1} \mathrm{H}$ NMR (500 MHz, DMSO- $\left.d_{6}\right)$ : $\delta=7.55\left(\mathrm{~s}, 2 \mathrm{H}, \mathrm{NH}_{2}\right) ; 6.02(\mathrm{~d}, J=8.5 \mathrm{~Hz}, 1 \mathrm{H}, \mathrm{H}-1) ; 5.50(\mathrm{t}, J=9.5 \mathrm{~Hz}, 1 \mathrm{H}, \mathrm{H}-3) ; 4.99(\mathrm{t}, J=9.5 \mathrm{~Hz}$, 2H, H-2, H-4); 4.30 (m, 1H, H-5); 4.03-3.99 (m, 2H, H-6a, H-6b); 2.31, 2.28, 2.22, 2.16 (4 × m, 8H, $\left.\mathrm{OCOCH}_{2}\right) ; 1.54-1.44\left(\mathrm{~m}, 8 \mathrm{H}, \mathrm{CH}_{2} \mathrm{CH}_{3}\right) ; 0.86,0.84,0.83,0.82\left(4 \times \mathrm{t}, J=7.5 \mathrm{~Hz}, 12 \mathrm{H}, \mathrm{CH}_{2} \mathrm{CH}_{3}\right)$, assignments were confirmed by ${ }^{1} \mathrm{H}-{ }^{1} \mathrm{H}$ gCOSY. ${ }^{13} \mathrm{C}$ NMR (125 MHz, DMSO- $\left.d_{6}\right): \delta=171.7,171.5$, 171.3, 171.0 (4 × OCOPr); 90.6 (C-1); 71.5, 71.4 (C-3, C-5); 69.8 (C-4); 67.7 (C-2); 66.6 (C-6); 35.1, 35.1, 35.0, $35.0\left(4 \times \mathrm{OCOCH}_{2}\right) ; 17.8,17.7,17.6,17.5\left(4 \times \mathrm{CH}_{2} \mathrm{CH}_{3}\right) ; 13.3,13.2,13.1,13.1(4 \times$ $\mathrm{CH}_{2} \mathrm{CH}_{3}$ ), assignments were confirmed by ${ }^{1} \mathrm{H}^{-}{ }^{13} \mathrm{C}$ HSQC. LRMS $\left(\mathrm{ESI}^{+}\right): \mathrm{m} / \mathrm{z}=562[\mathrm{M}+\mathrm{Na}]^{+}$. HRMS: Calcd for $\mathrm{C}_{22} \mathrm{H}_{37} \mathrm{~N}_{1} \mathrm{O}_{12} \mathrm{SNa}^{+}$562.1929, Found 562.1941.

1,2,3,4-Tetra-O-acetyl-6-sulfamoyl- $\boldsymbol{\beta}$-D-galactopyranose (10). The title compound 10 was prepared from 1,2,3,4-tetra-O-acetyl- $\beta$-D-galactopyranose according to general procedure 1 . Purification of the crude product by flash chromatography (1:1 EtOAc/hexane) afforded $\mathbf{1 0}$ (48\% yield) as a white solid. m.p. $=154{ }^{\circ} \mathrm{C} \cdot[\alpha]^{25}=+14(c=1.0$, chloroform $) . \mathrm{R}_{f}=0.64$ (3:1 EtOAc/hexane). ${ }^{1} \mathrm{H}$ NMR $(500 \mathrm{MHz}$, DMSO- $d_{6}$ ): $\delta=7.60$ (s, 2H, NH $H_{2}$ ); 5.91 (d, $J=8.5 \mathrm{~Hz}, 1 \mathrm{H}, \mathrm{H}-1$ ); 5.35 (dd, $J=10.0,3.5 \mathrm{~Hz}, 1 \mathrm{H}, \mathrm{H}-3$ ); 5.33 (br d, $J=3.5 \mathrm{~Hz}, 1 \mathrm{H}, \mathrm{H}-4$ ); 5.09 (dd, $J=9.5,8.5 \mathrm{~Hz}, 1 \mathrm{H}, \mathrm{H}-2$ ); 4.47 (br t, $J=6.0 \mathrm{~Hz}, 1 \mathrm{H}, \mathrm{H}-5$ ); 
4.04-3.99 (m, 2H, H-6a, H-6b); 2.13, 2.07, 2.02, 1.93 (4 × s, 12H, $\mathrm{OCOCH}_{3}$ ), assignments were

confirmed by ${ }^{1} \mathrm{H}-{ }^{1} \mathrm{H}$ gCOSY. ${ }^{13} \mathrm{C}$ NMR $\left(125 \mathrm{MHz}\right.$, DMSO- $\left.d_{6}\right): \delta=169.8,169.5,169.3,168.8(4 \times$ $\mathrm{OCOCH}_{3}$ ); 91.3 (C-1); 71.0 (C-5); 69.9 (C-3); 67.6 (C-2); 67.2 (C-4); 66.2 (C-6); 20.5, 20.4, 20.4, 20.3 $\left(4 \times \mathrm{OCOCH}_{3}\right)$, assignments were confirmed by ${ }^{1} \mathrm{H}_{-}{ }^{13} \mathrm{C}$ HSQC. LRMS $\left(\mathrm{ESI}^{+}\right): \mathrm{m} / \mathrm{z}=445\left[\mathrm{M}+\mathrm{NH}_{4}\right]^{+}$, $450[\mathrm{M}+\mathrm{Na}]^{+}$. HRMS: Calcd for $\mathrm{C}_{14} \mathrm{H}_{21} \mathrm{NO}_{12} \mathrm{SNa}^{+}$450.0677, Found 450.0678.

1,2,3,4-Tetra-O-acetyl-6-sulfamoyl- $\beta$-D-mannopyranose (11). The title compound 11 was prepared from 1,2,3,4-tetra-O-acetyl- $\beta$-D-mannopyranose according to general procedure 1 . Purification by flash chromatography (1:1 EtOAc/hexane) afforded 5 (15\% yield) as a colourless oil. $[\alpha]^{25}=-15(c=1.0$, chloroform). $\mathrm{R}_{f}=0.58$ (3:1 EtOAc/hexane). ${ }^{1} \mathrm{H}$ NMR (500 MHz, DMSO-d $\left.{ }_{6}\right): \delta=7.57$ (s, $\left.2 \mathrm{H}, \mathrm{NH}_{2}\right)$; 6.12 (br s, 1H, H-1); 5.38 (dd, $J=10.0,3.5$ Hz, 1H, H-3); 5.37 (br d, $J=3.5$ Hz, 1H, H-2); 5.02 (t, $J=$ 10.0 Hz, 1H, H-4); 4.15 (ddd, $J=10.0,5.5,2.5$ Hz, 1H, H-5); 4.05-4.00 (m, 2H, H-6a, H-6b); 2.15 (s, 3H, $\left.\mathrm{OCOCH}_{3}\right) ; 2.04$ (s, 6H, $\left.2 \times \mathrm{OCOCH}_{3}\right) ; 1.94$ (s, 3H, OCOCH ), assignments were confirmed by ${ }^{1} \mathrm{H}-$ ${ }^{1} \mathrm{H}_{\text {gCOSY}}{ }^{13} \mathrm{C}$ NMR (125 MHz, DMSO- $\left.d_{6}\right): \delta=169.8,169.4,169.4,168.1\left(4 \times \mathrm{OCOCH}_{3}\right) ; 90.1(\mathrm{C}-$

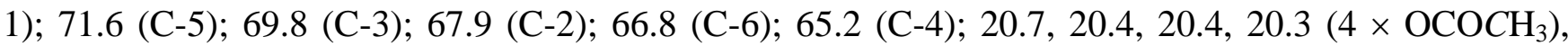
assignments were confirmed by ${ }^{1} \mathrm{H}^{-13} \mathrm{C}$ HSQC. LRMS $\left(\mathrm{ESI}^{+}\right): \mathrm{m} / \mathrm{z}=445\left[\mathrm{M}+\mathrm{NH}_{4}\right]^{+}, 450[\mathrm{M}+\mathrm{Na}]^{+}$. HRMS: Calcd for $\mathrm{C}_{14} \mathrm{H}_{21} \mathrm{NO}_{12} \mathrm{SNa}^{+}$450.0677, Found 450.0660 .

1,2,2',3,3',4',6-Hepta-O-acetyl-6'-sulfamoyl- $\boldsymbol{\beta}$-maltose (12). The title compound 12 was prepared from 1,2,2',3,3',4',6-hepta-O-acetyl- $\beta$-maltose according to general procedure 1 . The crude material was purified by flash chromatography (2:1 EtOAc/hexane) to give pure $\beta$-anomer 12 as a white solid (50\% yield). $\mathrm{R}_{f}=0.52$ (2:1 EtOAc/hexane). m.p. $=98-99{ }^{\circ} \mathrm{C} .[\alpha]^{25}{ }_{\mathrm{D}}=+40\left(c=1.0\right.$, chloroform). ${ }^{1} \mathrm{H}$ NMR (500 MHz, DMSO- $\left.d_{6}\right): \delta=7.51\left(\mathrm{~s}, 2 \mathrm{H}, \mathrm{NH}_{2}\right) ; 5.89$ (d, $\left.J=8.5 \mathrm{~Hz}, 1 \mathrm{H}, \mathrm{H}-1\right) ; 5.43$ (t, $J=9.5 \mathrm{~Hz}, 1 \mathrm{H}, \mathrm{H}-$ 3); 5.31 (d, $\left.J=4.0 \mathrm{~Hz}, 1 \mathrm{H}, \mathrm{H}-1^{\prime}\right) ; 5.20$ (t, $J=10.0 \mathrm{~Hz}, 1 \mathrm{H}, \mathrm{H}-3$ '); 4.95 (t, $J=9.5 \mathrm{~Hz}, 1 \mathrm{H}, \mathrm{H}-4$ '); 4.85 (dd, $J=10.5,3.5$ Hz, 1H, H-2'); 4.80 (dd, $J=9.5,8.5$ Hz, 1H, H-2); 4.37 (dd, $J=13.0,3.5$ Hz, 1H, H- 
6a); 4.12 (m, 2H, H-6b, H-5); 4.06-4.01 (m, 3H, H-5', H-6a', H-6b'); 3.99 (t, J = 9.5 Hz, 1H, H-4); 2.06, 2.04, 1.98, 1.97, 1.95, 1.94, $1.93(7 \times \mathrm{s}, 21 \mathrm{H}, \mathrm{OCOCH})$, assignments were confirmed by ${ }^{1} \mathrm{H}-{ }^{1} \mathrm{H}$ gCOSY. ${ }^{13} \mathrm{C}$ NMR (125 MHz, DMSO- $\left.d_{6}\right): \delta=170.4,170.1,169.8,169.8,169.5,169.3,168.9(7 \times$ $\left.\mathrm{OCOCH}_{3}\right)$; 95.4 (C-1'); 90.8 (C-1); 73.9, (C-3); 73.2 (C-5'); 72.3 (C-5); 70.9 (C-2); 69.5 (C-2'); 69.1 (C3'); 68.1 (C-4); 67.8 (C-4'); 66.6 (C-6'); 62.6 (C-6); 20.9, 20.7, 20.7, 20.6, 20.5, 20.4, $20.4(7 \times$ $\mathrm{OCOCH}_{3}$ ), assignments were confirmed by ${ }^{1} \mathrm{H}_{-}{ }^{13} \mathrm{C}$ HSQC and ${ }^{1} \mathrm{H}_{-}{ }^{13} \mathrm{C} \mathrm{HMBC}$. LRMS $\left(\mathrm{ESI}^{+}\right): \mathrm{m} / \mathrm{z}=738$ $[\mathrm{M}+\mathrm{Na}]^{+}$. HRMS: Calcd for $\mathrm{C}_{26} \mathrm{H}_{37} \mathrm{~N}_{1} \mathrm{O}_{20} \mathrm{SNa}^{+}$738.1522, Found 738.1548.

Methyl 2,3,4-tri-O-acetyl-6-sulfamoyl- $\boldsymbol{\alpha}$-D-glucopyranose (13). The title compound 13 was prepared from methyl 2,3,4-tri-O-acetyl- $\alpha$-D-glucopyranose according to general procedure 1 . Purification of the crude product by flash chromatography (1:2 acetone/hexane) afforded the 11 (61\% yield) as a colourless gum. $\mathrm{R}_{f}=0.29\left(1: 1 \mathrm{EtOAc/hexane).}{ }^{1} \mathrm{H}\right.$ NMR (500 MHz, DMSO- $\left.d_{6}\right): \delta=7.47$ (s, 2H, $\mathrm{NH}_{2}$ ); 5.30 (t, $\left.J=10.0 \mathrm{~Hz}, 1 \mathrm{H}, \mathrm{H}-3\right) ; 4.94$ (d, $\left.J=3.5 \mathrm{~Hz}, 1 \mathrm{H}, \mathrm{H}-1\right) ; 4.94$ (t, $\left.J=10.0 \mathrm{~Hz}, 1 \mathrm{H}, \mathrm{H}-4\right)$; 4.84 (dd, $J=10.0,3.5 \mathrm{~Hz}, 1 \mathrm{H}, \mathrm{H}-2)$; 4.07-4.04 (m, 2H, H-6a, H-6b); 3.98 (m, 1H, H-5); 3.35 (s, 3H, $\left.\mathrm{OCH}_{3}\right)$; 2.02, 1.99, $1.96\left(3 \times \mathrm{s}, 9 \mathrm{H}, \mathrm{OCOCH}_{3}\right)$, assignments were confirmed by ${ }^{1} \mathrm{H}-{ }^{1} \mathrm{H}$ gCOSY. ${ }^{13} \mathrm{C}$ NMR (125 MHz, DMSO- $\left.d_{6}\right): \delta=169.6,169.2,169.1\left(3 \times \mathrm{OCOCH}_{3}\right) ; 96.0(\mathrm{C}-1) ; 69.8(\mathrm{C}-2) ; 69.4(\mathrm{C}-$ 3); 68.2 (C-5); 66.9 (C-4); 66.8 (C-6); $54.9\left(\mathrm{OCH}_{3}\right)$; 20.2, 20.3, $20.3\left(3 \times \mathrm{OCOCH}_{3}\right)$, assignments were confirmed by ${ }^{1} \mathrm{H}^{-13} \mathrm{C}$ HSQC. LRMS $\left(\mathrm{ESI}^{+}\right): \mathrm{m} / \mathrm{z}=422[\mathrm{M}+\mathrm{Na}]^{+}$. HRMS: Calcd for $\mathrm{C}_{13} \mathrm{H}_{21} \mathrm{~N}_{1} \mathrm{O}_{11} \mathrm{SNa}^{+}$ 422.0728, Found 422.0726.

General procedure 2 - synthesis of sulfamates 14-18. Fully deprotected sulfamates were prepared by treating a solution of the per- $\mathrm{O}$-acetylated parent compound (1.0 equiv.) in anhydrous $\mathrm{MeOH}$ at $0{ }^{\circ} \mathrm{C}$ with methanolic sodium methoxide $(0.05 \mathrm{M}$ final concentration), final $\mathrm{pH}=12$. The reaction was warmed to rt and left to stir until full deprotection was evident by TLC (30 min $-2 \mathrm{~h}$ ). The solution was 
neutralized with Amberlite IR-120 $\left[\mathrm{H}^{+}\right]$, filtered and the resin washed several times with methanol. The solvent was evaporated under reduced pressure and the product lyophilized to dryness.

6-Sulfamoyl- $\boldsymbol{\alpha}, \boldsymbol{\beta}$-D-glucopyranose (14). The title compound $\mathbf{1 4}$ was prepared from the $\mathbf{7}$ according to general procedure 2 and obtained as a hygroscopic white solid (91\% yield, $\alpha / \beta 4 / 6) . R_{f}=0.53$ (9:1 $\mathrm{CH}_{3} \mathrm{CN} / \mathrm{H}_{2} \mathrm{O}$ ). ${ }^{1} \mathrm{H}$ NMR (500 MHz, DMSO- $\left.\mathrm{d}_{6}\right): \delta=7.43$ (s, $\left.1.2 \mathrm{H}, \mathrm{NH}_{2 \beta}\right) ; 7.40$ (s, 0.8H, $\mathrm{NH}_{2 \alpha}$ ); 6.72 (d, $\left.J=6.5 \mathrm{~Hz}, 0.6 \mathrm{H}, \mathrm{OH}-1_{\beta}\right) ; 6.41$ (d, $\left.J=4.5 \mathrm{~Hz}, 0.4 \mathrm{H}, \mathrm{OH}-1_{\alpha}\right) ; 5.13\left(\mathrm{~d}, J=5.5 \mathrm{~Hz}, 0.6 \mathrm{H}, \mathrm{OH}-4_{\beta}\right) ; 5.08$ (d, $\left.J=5.5 \mathrm{~Hz}, 0.4 \mathrm{H}, \mathrm{OH}-4_{\alpha}\right) ; 4.95$ (br s, $\left.0.6 \mathrm{H}, \mathrm{OH}-3_{\beta}\right) ; 4.92$ (t, $J=3.5 \mathrm{~Hz}, 0.4 \mathrm{H}, \mathrm{H}-1_{\alpha}$ ); 4.92 (br s, $0.6 \mathrm{H}$, $\mathrm{OH}-2_{\beta}$ ); 4.76 (br s, $0.4 \mathrm{H}, \mathrm{OH}-3_{\alpha}$ ); 4.54 (d, $J=5.0 \mathrm{~Hz}, 0.4 \mathrm{H}, \mathrm{OH}-3_{\alpha}$ ); 4.32 (br d, $J=7.0 \mathrm{~Hz}, 0.6 \mathrm{H}, \mathrm{H}-1_{\beta}$ ); 4.28 (dd, $J=10.5,1.5 \mathrm{~Hz}, 0.6 \mathrm{H}, \mathrm{H}-6 \mathrm{a}_{\beta}$ ); 4.22 (dd, $J=10.0,1.5 \mathrm{~Hz}, 0.4 \mathrm{H}, \mathrm{H}-6 \mathrm{a}_{\alpha}$ ); 4.02 (dd, $J=10.5,6.5$ Hz, 0.4H, H-6b $\mathrm{b}_{\alpha}$ ); 3.99 (dd, $J=10.5,7.0 \mathrm{~Hz}, 0.6 \mathrm{H}, \mathrm{H}-6 \mathrm{~b}_{\beta}$ ); 3.82 (m, 0.4H, H-5 ) $^{2} 3.44$ (br t, $J=9.0 \mathrm{~Hz}$, 0.4H, H-3 $3_{\alpha}$ ); 3.40 (m, 0.6H, H-5 $)$; 3.16 (m, 0.6H, H-3 $3_{\beta}$ ); 3.13 (m, 0.4H, H-2 ${ }_{\alpha}$ ); 3.04-3.02 (m, 1H, H-4, $\left.\mathrm{H}-4_{\beta}\right) ; 2.91$ (m, 0.4H, H-2 $)$, assignments were confirmed by ${ }^{1} \mathrm{H}-{ }^{1} \mathrm{H}$ gCOSY.${ }^{13} \mathrm{C}$ NMR $(125 \mathrm{MHz}$, DMSO- $\left.d_{6}\right): \delta=96.9\left(\mathrm{C}-1_{\beta}\right) ; 92.3\left(\mathrm{C}-1_{\alpha}\right) ; 76.5\left(\mathrm{C}-3_{\beta}\right) ; 74.7\left(\mathrm{C}-2_{\beta}\right) ; 73.5\left(\mathrm{C}-5_{\beta}\right) ; 73.0\left(\mathrm{C}-3_{\alpha}\right) ; 72.1\left(\mathrm{C}-2_{\alpha}\right)$; $70.4\left(\mathrm{C}-4_{\alpha}\right)$; $70.0\left(\mathrm{C}-4_{\beta}\right) ; 69.2$ (C-6 $\left.6_{\alpha}\right) ; 69.0$ (C-5 $\left.5_{\alpha}\right) ; 68.9\left(\mathrm{C}-6_{\beta}\right)$, assignments were confirmed by ${ }^{1} \mathrm{H}^{-13} \mathrm{C}$ HSQC. LRMS $\left(\mathrm{ESI}^{+}\right): \mathrm{m} / \mathrm{z}=282[\mathrm{M}+\mathrm{Na}]^{+}$. HRMS: Calcd for $\mathrm{C}_{6} \mathrm{H}_{13} \mathrm{NO}_{8} \mathrm{SNa}^{+}$282.0254, Found 282.0251.

6-Sulfamoyl- $\boldsymbol{\alpha}, \boldsymbol{\beta}$-D-galactopyranose (15). The title compound 15 was prepared from 10 according to general procedure 2. Purification of the crude product by flash chromatography (95:5 $\mathrm{CH}_{3} \mathrm{CN} / \mathrm{H}_{2} \mathrm{O}$ ) afforded 4 (71\% yield, $\alpha / \beta 4 / 6)$ as a colourless oil. $\mathrm{R}_{f}=0.28\left(95: 5 \mathrm{CH}_{3} \mathrm{CN} / \mathrm{H}_{2} \mathrm{O}\right) .{ }^{1} \mathrm{H} \mathrm{NMR}(500 \mathrm{MHz}$, DMSO-d $\left.d_{6}\right): \delta=7.45$ (s, $\left.1.2 \mathrm{H}, \mathrm{NH}_{2 \beta}\right) ; 7.43$ (s, $0.8 \mathrm{H}, \mathrm{NH}_{2 \alpha}$ ); 6.64 (d, $\left.J=6.5 \mathrm{~Hz}, 0.6 \mathrm{H}, \mathrm{OH}-1_{\beta}\right) ; 6.29$ (d, $J$ $\left.=4.5 \mathrm{~Hz}, 0.4 \mathrm{H}, \mathrm{OH}-1_{\alpha}\right) ; 4.96\left(\mathrm{t}, J=4.0 \mathrm{~Hz}, 0.4 \mathrm{H}, \mathrm{H}-1_{\alpha}\right) ; 4.74$ (d, $\left.J=4.5 \mathrm{~Hz}, 1 \mathrm{H}\right), 4.72$ (d, $J=5.5 \mathrm{~Hz}$, 0.4H), 4.62 (d, $J=4.5 \mathrm{~Hz}, 0.6 \mathrm{H}), 4.56(\mathrm{~m}, 0.6 \mathrm{H}), 4.32$ (d, $J=5.5 \mathrm{~Hz}, 0.4 \mathrm{H})(\mathrm{OH}-2, \mathrm{OH}-3, \mathrm{OH}-4) ; 4.27$ (t, $J=7.0 \mathrm{~Hz}, 0.6 \mathrm{H}, \mathrm{H}-\mathrm{1}_{\beta}$ ); 4.12-4.06 (m, 2H, H-6a $\mathrm{a}_{\alpha}, \mathrm{H}-6 \mathrm{a}_{\beta}, \mathrm{H}-6 \mathrm{~b}_{\alpha}, \mathrm{H}-6 \mathrm{~b}_{\beta}$ ); 3.70 (br t, $J=3.5 \mathrm{~Hz}, 0.4 \mathrm{H}$, H-5 ${ }_{\alpha}$ ); 3.66 (br t, $J=6.0 \mathrm{~Hz}, 0.6 \mathrm{H}, \mathrm{H}-3_{\beta}$ ); 3.62 (br t, $J=3.5 \mathrm{~Hz}, 0.6 \mathrm{H}, \mathrm{H}-5_{\beta}$ ); 3.59 (m, 0.4H, H-3 ${ }_{\alpha}$ ); 3.52 
(m, 0.4H, H-2 $)_{\alpha}$; 3.31 (dd, $J=5.0,3.5 \mathrm{~Hz}, 0.4 \mathrm{H}, \mathrm{H}-4_{\alpha}$ ); 3.29 (dd, $J=5.0,3.5 \mathrm{~Hz}, 0.6 \mathrm{H}, \mathrm{H}-4_{\beta}$ ); 3.24 (m,

$\left.0.4 \mathrm{H}, \mathrm{H}-2_{\beta}\right)$, assignments were confirmed by ${ }^{1} \mathrm{H}-{ }^{1} \mathrm{H}$ gCOSY. ${ }^{13} \mathrm{C}$ NMR $\left(125 \mathrm{MHz}\right.$, DMSO- $\left.d_{6}\right): \delta=97.4$ $\left(\mathrm{C}-1_{\beta}\right) ; 92.7\left(\mathrm{C}-1_{\alpha}\right) ; 75.8\left(\mathrm{C}-4_{\alpha}\right) ; 73.1\left(\mathrm{C}-4_{\beta}\right) ; 72.1\left(\mathrm{C}-5_{\beta}\right) ; 71.8\left(\mathrm{C}-3_{\beta}\right) ; 69.4\left(\mathrm{C}-5_{\alpha}\right) ; 69.2\left(\mathrm{C}-2_{\alpha}\right) ; 69.0(\mathrm{C}-$ $\left.3_{\alpha}\right) ; 68.8\left(\mathrm{C}-2_{\beta}\right) ; 67.9\left(\mathrm{C}-6_{\beta}\right) 67.3\left(\mathrm{C}-6_{\alpha}\right)$, assignments were confirmed by ${ }^{1} \mathrm{H}_{-}{ }^{13} \mathrm{C}$ HSQC. LRMS (ESI $\left.{ }^{+}\right)$: $m / z=282[\mathrm{M}+\mathrm{Na}]^{+}$. HRMS: Calcd for $\mathrm{C}_{6} \mathrm{H}_{13} \mathrm{NO}_{8} \mathrm{SNa}^{+}$282.0254, Found 282.0268.

6-Sulfamoyl- $\boldsymbol{\alpha}, \boldsymbol{\beta}$-D-mannopyranose (16). The title compound $\mathbf{1 6}$ was prepared from $\mathbf{1 1}$ according to general procedure 1 . Purification of the crude product by flash chromatography $\left(95: 5 \mathrm{CH}_{3} \mathrm{CN} / \mathrm{H}_{2} \mathrm{O}\right)$ afforded 16 (36\% yield, $\alpha / \beta$ 4/6) as a colourless oil. $\mathrm{R}_{f}=0.32\left(95: 5 \mathrm{CH}_{3} \mathrm{CN} / \mathrm{H}_{2} \mathrm{O}\right) .{ }^{1} \mathrm{H} \mathrm{NMR}(500 \mathrm{MHz}$, DMSO- $\left.d_{6}\right): \delta=7.42\left(\mathrm{~s}, 0.8 \mathrm{H}, \mathrm{NH}_{2 \alpha}\right) ; 7.40\left(\mathrm{~s}, 1.2 \mathrm{H}, \mathrm{NH}_{2 \beta}\right) ; 6.44\left(\mathrm{~d}, J=4.5 \mathrm{~Hz}, 0.6 \mathrm{H}, \mathrm{OH}-1_{\beta}\right) ; 6.32(\mathrm{~d}, J$ $\left.=8.0 \mathrm{~Hz}, 0.4 \mathrm{H}, \mathrm{OH}-1_{\alpha}\right) ; 4.96\left(\mathrm{~d}, J=3.0 \mathrm{~Hz}, 0.4 \mathrm{H}, \mathrm{OH}-4_{\alpha}\right) ; 4.92\left(\mathrm{~d}, J=4.5 \mathrm{~Hz}, 0.6 \mathrm{H}, \mathrm{OH}-4_{\beta}\right) ; 4.88(\mathrm{~d}, J$ $\left.=4.0 \mathrm{~Hz}, 0.6 \mathrm{H}, \mathrm{H}-1_{\beta}\right) ; 4.67$ (d, $\left.J=4.0 \mathrm{~Hz}, 0.6 \mathrm{H}, \mathrm{OH}-2_{\beta}\right) ; 4.65$ (br s, $\left.0.4 \mathrm{H}, \mathrm{OH}-2_{\alpha}\right) ; 4.60$ (d, $J=8.0 \mathrm{~Hz}$, $0.4 \mathrm{H}, \mathrm{H}-1_{\alpha}$ ); 4.57 (d, $\left.J=6.0 \mathrm{~Hz}, 0.6 \mathrm{H}, \mathrm{OH}-3_{\beta}\right) ; 4.54$ (d, $\left.J=4.5 \mathrm{~Hz}, 0.4 \mathrm{H}, \mathrm{OH}-3_{\alpha}\right) ; 4.29$ (br d, $J=10.5$ Hz, 0.4H, H-6a $\mathrm{a}_{\alpha}$ ); 4.26 (dd, $J=10.0,1.5 \mathrm{~Hz}, 0.6 \mathrm{H}, \mathrm{H}-6 \mathrm{a}_{\beta}$ ); 4.03 (dd, $J=10.0,7.0 \mathrm{~Hz}, 0.6 \mathrm{H}, \mathrm{H}-6 \mathrm{~b}_{\beta}$ ); 4.00 (m, 0.4H, H-6b $\mathrm{b}_{\alpha}$ ); 3.76 (m, 0.6H, H-5 ${ }_{\beta}$ ); 3.57-3.53 (m, 1.6H, H-2 $\left.{ }_{\beta}, \mathrm{H}-3_{\alpha}, \mathrm{H}-3_{\beta}\right)$; 3.36 (m, 0.4H, H$4_{\beta}$ ); 3.31-3.30 (m, $1.2 \mathrm{H}, \mathrm{H}-2_{\alpha}, \mathrm{H}-4_{\alpha}, \mathrm{H}-5_{\alpha}$ ), assignments were confirmed by ${ }^{1} \mathrm{H}-{ }^{1} \mathrm{H}$ gCOSY. ${ }^{13} \mathrm{C}$ NMR (125 MHz, DMSO-d $\left.)_{6}\right): \delta=94.2\left(\mathrm{C}-1_{\alpha}\right) ; 94.1\left(\mathrm{C}-1_{\beta}\right) ; 74.0\left(\mathrm{C}-5_{\alpha}\right) ; 73.5\left(\mathrm{C}-3_{\alpha}\right) ; 71.5\left(\mathrm{C}-2_{\alpha}\right) ; 71.3\left(\mathrm{C}-3_{\beta}\right)$; $70.5\left(\mathrm{C}-2_{\beta}\right) ; 70.4\left(\mathrm{C}-5_{\beta}\right) ; 69.3\left(\mathrm{C}-6_{\beta}\right) ; 69.1\left(\mathrm{C}-6_{\alpha}\right) ; 67.0\left(\mathrm{C}-4_{\beta}\right)$; $66.6\left(\mathrm{C}-4_{\alpha}\right)$, assignments were confirmed by ${ }^{1} \mathrm{H}^{-13} \mathrm{C}$ HSQC. LRMS $\left(\mathrm{ESI}^{+}\right): \mathrm{m} / \mathrm{z}=282[\mathrm{M}+\mathrm{Na}]^{+}$. HRMS: Calcd for $\mathrm{C}_{6} \mathrm{H}_{13} \mathrm{NO}_{8} \mathrm{SNa}^{+}$282.0254, Found 282.0258.

6'-Sulfamoyl- $\boldsymbol{\alpha}, \boldsymbol{\beta}$-maltose (17). The title compound 17 was prepared from 12 according to general procedure 2. Purification of the crude product by flash chromatography $\left(95: 5 \mathrm{CH}_{3} \mathrm{CN} / \mathrm{H}_{2} \mathrm{O}\right)$ afforded 17 (37\% yield, $\alpha / \beta$ 4/6) as a hygroscopic white solid. $\mathrm{R}_{f}=0.32\left(95: 5 \mathrm{CH}_{3} \mathrm{CN} / \mathrm{H}_{2} \mathrm{O}\right) .{ }^{1} \mathrm{H}$ NMR $(500 \mathrm{MHz}$, DMSO- $\left.d_{6}\right): \delta=7.40\left(\mathrm{~s}, 2 \mathrm{H}, \mathrm{NH}_{2}\right) ; 6.68,6.34,5.43,5.15(4 \times$ br s, $4 \mathrm{H}, \mathrm{OH}) ; 5.08,5.04(2 \times \mathrm{d}, J=3.5$ $\left.\mathrm{Hz}, 1 \mathrm{H}, \mathrm{H}-1_{\alpha}^{\prime}, \mathrm{H}-1_{\beta}^{\prime}\right) ; 4.97$ (br s, $\left.1 \mathrm{H}, \mathrm{OH}\right) ; 4.91$ (br s, 0.4H, H-1 ${ }_{\alpha}$ ); 4.54, 4.44 (2 × br s, 2H, OH); 4.31 
(d, $J=7.5 \mathrm{~Hz}, 0.6 \mathrm{H}, \mathrm{H}-1_{\beta}$ ); 4.19 (br d, $\left.J=10.5 \mathrm{~Hz}, 1 \mathrm{H}, \mathrm{H}-6 \mathrm{a}^{\prime}\right) ; 4.10$ (dd, $\left.J=10.5,5.5 \mathrm{~Hz}, 1 \mathrm{H}, \mathrm{H}-6 \mathrm{~b}^{\prime}\right)$;

3.73 (m, 1H, H-5'); 3.69-3.64 (m, 2H, H-6a, H-4); 3.62-3.58 (m, 1H, H-6b); 3.50 (m, 0.4H, H-3 $)$; 3.403.37 (m, 2.2H, H-3 ${ }_{\beta}, \mathrm{H}-3$ ', H-5 ${ }_{\beta}$ ); 3.32 (m, 0.4 H, H-5 ${ }_{\alpha}$ ); 3.25-3.18 (m, 1.4H, H-2 $\alpha, \mathrm{H}-2$ '); 3.09 (t, $J=9.5$ $\left.\mathrm{Hz}, 1 \mathrm{H}, \mathrm{H}-4^{\prime}\right) ; 2.95$ (t, $\left.J=0.6 \mathrm{H}, \mathrm{H}-2_{\beta}\right)$, assignments were confirmed by ${ }^{1} \mathrm{H}-{ }^{1} \mathrm{H}$ gCOSY. ${ }^{13} \mathrm{C}$ NMR (125 MHz, DMSO- $\left.d_{6}\right): \delta=100.8,100.6\left(\mathrm{C}-1_{\alpha}^{\prime}, \mathrm{C}-1_{\beta}^{\prime}\right) ; 96.8\left(\mathrm{C}-1_{\beta}\right) ; 92.2\left(\mathrm{C}-1_{\alpha}\right) ; 80.2\left(\mathrm{C}-5_{\alpha}\right) ; 79.5\left(\mathrm{C}-5_{\beta}\right) ; 76.6$ $\left(\mathrm{C}-3_{\beta}\right) ; 75.2\left(\mathrm{C}-2_{\alpha}\right) ; 74.5\left(\mathrm{C}-2_{\beta}\right) ; 73.3,73.2\left(\mathrm{C}-3_{\alpha}^{\prime}, \mathrm{C}-3_{\beta}^{\prime}\right) ; 73.0\left(\mathrm{C}-4_{\alpha}\right.$ or $\left.\mathrm{C}-4_{\beta}\right) ; 72.5,72.4\left(\mathrm{C}-2^{\prime}{ }_{\alpha}, \mathrm{C}-2_{\beta}^{\prime}\right)$;

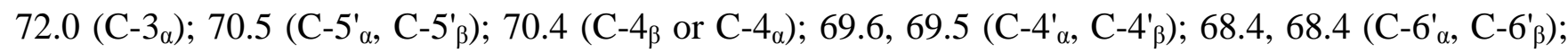
60.7, $60.6\left(\mathrm{C}-6_{\alpha}, \mathrm{C}-6_{\beta}\right)$, assignments were confirmed by ${ }^{1} \mathrm{H}-{ }^{13} \mathrm{C}$ HSQC. LRMS $\left(\mathrm{ESI}^{+}\right): \mathrm{m} / \mathrm{z}=444[\mathrm{M}+$ $\mathrm{Na}^{+}$, LRMS (ESI): $\mathrm{m} / \mathrm{z}=420[\mathrm{M}-\mathrm{H}]^{-}, 455[\mathrm{M}+\mathrm{Cl}]^{-}$. HRMS: Calcd for $\mathrm{C}_{12} \mathrm{H}_{23} \mathrm{~N}_{1} \mathrm{O}_{13} \mathrm{SNa}^{+}$444.0782, Found 444.0797.

Methyl 6-sulfamoyl-a-D-glucopyranose (18). The title compound 18 was prepared from compound 13 according to general procedure 2. The crude product was purified by flash chromatography (9:1 $\left.\mathrm{CH}_{3} \mathrm{CN} / \mathrm{H}_{2} \mathrm{O}\right)$ affording 18 (94\% yield) as a hygroscopic white solid. $[\alpha]^{25}=+30(c=1.0$, methanol). $\mathrm{R}_{f}=0.50\left(9: 1 \mathrm{CH}_{3} \mathrm{CN} / \mathrm{H}_{2} \mathrm{O}\right) .{ }^{1} \mathrm{H}$ NMR $\left(500 \mathrm{MHz}, \mathrm{DMSO}-d_{6}\right): \delta=7.43\left(\mathrm{NH}_{2}\right) ; 5.14(\mathrm{~d}, J=6.0 \mathrm{~Hz}, 1 \mathrm{H}$, $\mathrm{OH}-4) ; 4.86$ (d, $J=5.0 \mathrm{~Hz}, 1 \mathrm{H}, \mathrm{OH}-3) ; 4.78$ (d, $J=6.0 \mathrm{~Hz}, 1 \mathrm{H}, \mathrm{OH}-2) ; 4.56$ (d, $J=4.0 \mathrm{~Hz}, 1 \mathrm{H}, \mathrm{H}-1)$; 4.26 (m, 1H, H-6a); 4.05 (m, 1H, H-6b); 3.58 (m, 1H, H-5); 3.39 (m, 1H, H-3); 3.27 (s, 3H, OCH $)$; 3.23 (m, 1H, H-2), 3.04 (m, 1H, H-4), assignments were confirmed by ${ }^{1} \mathrm{H}-{ }^{1} \mathrm{H}$ gCOSY. ${ }^{13} \mathrm{C}$ NMR (125 MHz, DMSO-d $\left.)_{6}\right): \delta=99.7$ (C-1); 73.2 (C-3); 71.7 (C-5); 70.1 (C-4); 69.5 (C-5); 68.6 (C-6); 54.5 $\left(\mathrm{OCH}_{3}\right)$, assignments were confirmed by ${ }^{1} \mathrm{H}^{13}{ }^{13} \mathrm{C}$ HSQC. LRMS $\left(\mathrm{ESI}^{+}\right): \mathrm{m} / \mathrm{z}=296[\mathrm{M}+\mathrm{Na}]^{+}$; HRMS: Calcd for $\mathrm{C}_{7} \mathrm{H}_{15} \mathrm{~N}_{1} \mathrm{O}_{8} \mathrm{SNa}^{+}$296.0411, Found 296.0424.

\section{Acknowledgement}

This work was financed by the Australian Research Council (Grant number DP0877554 to S.-A.P.) and in part an EU grant of the $7^{\text {th }}$ framework programme (METOXIA project to C.T.S.). We thank 
Associate Professor Courtney Aldrich for guidance with the preparation and handling of sulfamoyl

chloride.

\section{Supporting Information Available}

${ }^{1} \mathrm{H}$ and ${ }^{13} \mathrm{C}$ NMR spectra for sulfamates 7-18 and novel intermediates and the synthesis of all intermediates. This material is available free of charge via the Internet at http://pubs.acs.org.

\section{References}

1. Supuran, C. T. Carbonic anhydrases: novel therapeutic applications for inhibitors and activators. Nat. Rev. Drug Discov. 2008, 7, 168-181.

2. Krishnamurthy, V. M.; Kaufman, G. K.; Urbach, A. R.; Gitlin, I.; Gudiksen, K. L.; Weibel, D. B.; Whitesides, G. M. Carbonic Anhydrase as a Model for Biophysical and Physical-Organic Studies of Proteins and Protein-Ligand Binding. Chem. Rev. 2008, 108, 946-1051.

3. Svastova, E.; Hulikova, A.; Rafajova, M.; Zatovicova, M.; Gibadulinova, A.; Casini, A.; Cecchi, A.; Scozzafava, A.; Supuran, C. T.; Pastorek, J.; Pastoreková, S. Hypoxia activates the capacity of tumor-associated carbonic anhydrase IX to acidify extracellular pH. FEBS Letters 2004, 577, 439-445.

4. $\quad$ Chiche, J.; Ilc, K.; Laferriere, J.; Trottier, E.; Dayan, F.; Mazure, N. M.; Brahimi-Horn, M. C.; Pouyssegur, J. Hypoxia-Inducible Carbonic Anhydrase IX and XII Promote Tumor Cell Growth by Counteracting Acidosis through the Regulation of the Intracellular pH. Cancer Res. 2009, 69, 358-368.

5. Swietach, P.; Vaughan-Jones, R.; Harris, A. Regulation of tumor $\mathrm{pH}$ and the role of carbonic anhydrase 9. Cancer Metastasis Rev. 2007, 26, 299-310.

6. $\quad$ Chiche, J.; Brahimi-Horn, M.; Pouysségur, J. Tumour hypoxia induces a metabolic shift causing acidosis: a common feature in cancer. $J$ Cell Mol Med 2010, 14, 771-794.

7. Martinez-Zaguilan, R.; Seftor, E.; Seftor, R.; Chu, Y.; Gillies , R.; Hendrix, M. Acidic pH enhances the invasive behavior of human melanoma cells. Clin. Exp. Metastasis 1996, 14, 176-186.

8. Jean-Yves, W.; Marouan, R.; Andrea, S.; Jean-Louis, M.; Claudiu, S. Carbonic anhydrase IX: A new druggable target for the design of antitumor agents. Med. Res. Rev. 2008, 28, 445-463.

9. Winum, J.-Y.; Scozzafava, A.; Montero, J.-L.; Supuran, C. T. New zinc binding motifs in the design of selective carbonic anhydrase inhibitors. Mini Rev. Med. Chem. 2006, 6, 921-936.

10. Wilkinson, B. L.; Bornaghi, L. F.; Houston, T. A.; Innocente, A.; Supuran, C. T.; Poulsen, S.-A. A novel class of carbonic anhydrase inhibitors: Glycoconjugate benzene sulfonamides prepared by "click-tailing". J. Med. Chem. 2006, 49, 6539-6548.

11. Wilkinson, B. L.; Bornaghi, L. F.; Houston, T. A.; Innocenti, A.; Vullo, D.; Supuran, C. T.; Poulsen, S.-A. Carbonic Anhydrase Inhibitors: Inhibition of Isozymes I, II, and IX with Triazole-Linked O-Glycosides of Benzene Sulfonamides. J. Med. Chem. 2007, 50, 1651-1657.

12. Wilkinson, B. L.; Bornaghi, L. F.; Houston, T. A.; Innocenti, A.; Vullo, D.; Supuran, C. T.; Poulsen, S.-A. Inhibition of membrane-associated carbonic anhydrase isozymes IX, XII and XIV with a library of glycoconjugate benzenesulfonamides. Bioorg. Med. Chem. Lett. 2007, 17, 987-992.

13. Wilkinson, B. L.; Innocenti, A.; Vullo, D.; Supuran, C. T.; Poulsen, S.-A. Inhibition of Carbonic Anhydrases with Glycosyltriazole Benzene Sulfonamides. J. Med. Chem. 2008, 51, 1945-1953. 
14. Lopez, M.; Bornaghi, L. F.; Innocenti, A.; Vullo, D.; Charman, S. A.; Supuran, C. T.; Poulsen, S.-A. Sulfonamide Linked Neoglycoconjugates - A New Class of Inhibitors for Cancer-Associated Carbonic Anhydrases. J. Med. Chem. 2010, 53, 2913-2926.

15. Singer, M.; Lopez, M.; Bornaghi, L. F.; Innocenti, A.; Vullo, D.; Supuran, C. T.; Poulsen, S.-A. Inhibition of carbonic anhydrase isozymes with benzene sulfonamides incorporating thio, sulfinyl and sulfonyl glycoside moieties. Bioorg. Med. Chem. Lett. 2009, 19, 2273-2276.

16. Meutermans, W.; Le, G. T.; Becker, B. Carbohydrates as scaffolds in drug discovery. ChemMedChem 2006, 1, 1164-1194.

17. Boltje, T. J.; Buskas, T.; Boons, G.-J. Opportunities and challenges in synthetic oligosaccharide and glycoconjugate research. Nat. Chem. 2009, 1, 611-622.

18. Winum, J.-Y.; Poulsen, S.-A.; Supuran, C. T. Therapeutic applications of glycosidic carbonic anhydrase inhibitors. Med. Res. Rev. 2009, 29, 419-435.

19. Lopez, M.; Paul, B.; Hofmann, A.; Morizzi, J.; Wu, Q. K.; Charman, S. A.; Innocenti, A.; Vullo, D.; Supuran, C. T.; Poulsen, S.-A. S-Glycosyl Primary Sulfonamides - A New Structural Class for Selective Inhibition of Cancer-Associated Carbonic Anhydrases. J. Med. Chem. 2009, 52, 6421-6432.

20. Maryanoff, B. E. Pharmaceutical "Gold" from Neurostabilizing Agents: Topiramate and Successor Molecules. J. Med. Chem. 2009, 52, 3431-3440.

21. Vullo, D.; Innocenti, A.; Nishimori, I.; Pastorek, J.; Scozzafava, A.; Pastoreková, S.; Supuran, C. T. Carbonic anhydrase inhibitors. Inhibition of the transmembrane isozyme XII with sulfonamides--a new target for the design of antitumor and antiglaucoma drugs? Bioorg. Med. Chem. Lett. 2005, 15, 963969.

22. Lavis, L. D. Ester Bonds in Prodrugs. ACS Chem. Biol. 2008, 3, 203-206.

23. Di, L.; Kerns, E. H.; Hong, Y.; Chen, H. Development and application of high throughput plasma stability assay for drug discovery. Int. J. Pharm. 2005, 297, 110-119.

24. Sarkar, A. K.; Fritz, T. A.; Taylor, W. H.; Esko, J. D. Disaccharide uptake and priming in animal

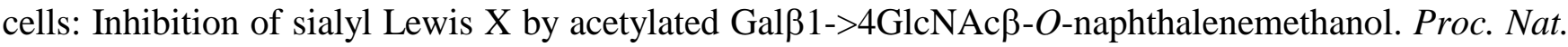
Acad. Sci. U.S.A. 1995, 92, 3323-3327.

25. Aich, U.; Campbell, C. T.; Elmouelhi, N.; Weier, C. A.; Sampathkumar, S.-G.; Choi, S. S.; Yarema, K. J. Regioisomeric SCFA Attachment to Hexosamines Separates Metabolic Flux from Cytotoxicity and MUC1 Suppression. ACS Chem. Biol. 2008, 3, 230-240.

26. Lee, G. S.; Lee, Y.-J.; Choi, S. Y.; Park, Y. S.; Yoon, K. B. Self-Assembly of $\alpha$-Glucosidase and D-Glucose-Tethering Zeolite Crystals into Fibrous Aggregates. J. Am. Chem. Soc. 2000, 122, 1215112157.

27. Randazzo, G.; Capasso, R.; Cicala, M. R.; Evidente, A. A simple method for detritylation of carbohydrate derivatives. Carbohydr. Res. 1980, 85, 298-301.

28. MacCoss, M.; Cameron, D. J. Facile detritylation of nucleoside derivatives by using trifluoroacetic acid. Carbohydr. Res. 1978, 60, 206-209.

29. Okada, M.; Iwashita, S.; Koizumi, N. Efficient general method for sulfamoylation of a hydroxyl group. Tetrahedron Lett. 2000, 41, 7047-7051.

30. Zemplén, G. Degradation of the reducing bioses. I. Direct determination of the constitution of cellobiose. Ber. Deutsch. Chem. Ges. 1926, 59, 1254-1266.

31. Khalifah, R. G. The Carbon Dioxide Hydration Activity of Carbonic Anhydrase. J. Biol. Chem. 1971, 246, 2561-2573.

32. Lopez, M.; Drillaud, N.; Bornaghi, L. F.; Poulsen, S.-A. Synthesis of S-Glycosyl Primary Sulfonamides. J. Org. Chem. 2009, 74, 2811-2816.

33. Palm, K.; Stenberg, P.; Luthman, K.; Artursson, P. Polar molecular surface properties predict the intestinal absorption of drugs in humans. Pharm. Res. 1997, 568-571.

34. $\quad$ Lipophilicity. In Drug-like Properties: Concepts, Structure Design and Methods: from ADME to Toxicity Optimization, 1st ed.; Kerns, E. H.; Di, L., Eds. Academic Press: London, 2008; pp 43-47. 
35. Zhu, C.; Jiang, L.; Chen, T.-M.; Hwang, K.-K. A comparative study of artificial membrane permeability assay for high throughput profiling of drug absorption potential. Eur. J. Med. Chem. 2002, 37, 399-407.

36. Kerns, E. H.; Di, L. Permeability Methods. In Drug-like Properties: Concepts, Structure Design and Methods: from ADME to Toxicity Optimization, Kerns, E. H.; Di, L., Eds. Academic Press: London, 2008; pp 287-298.

37. Reynolds, C. H.; Tounge, B. A.; Bembenek, S. D. Ligand Binding Efficiency: Trends, Physical Basis, and Implications. J. Med. Chem. 2008, 51, 2432-2438.

38. Perola, E. An Analysis of the Binding Efficiencies of Drugs and Their Leads in Successful Drug Discovery Programs. J. Med. Chem. 2010, 53, 2986-2997.

39. Neres, J.; Labello, N. P.; Somu, R. V.; Boshoff, H. I.; Wilson, D. J.; Vannada, J.; Chen, L.; Barry, C. E.; Bennett, E. M.; Aldrich, C. C. Inhibition of Siderophore Biosynthesis in Mycobacterium tuberculosis with Nucleoside Bisubstrate Analogues: Structure-Activity Relationships of the Nucleobase Domain of 5'-O-[N-(Salicyl)sulfamoyl]adenosine. J. Med. Chem. 2008, 51, 5349-5370.

Table of Contents Graphic

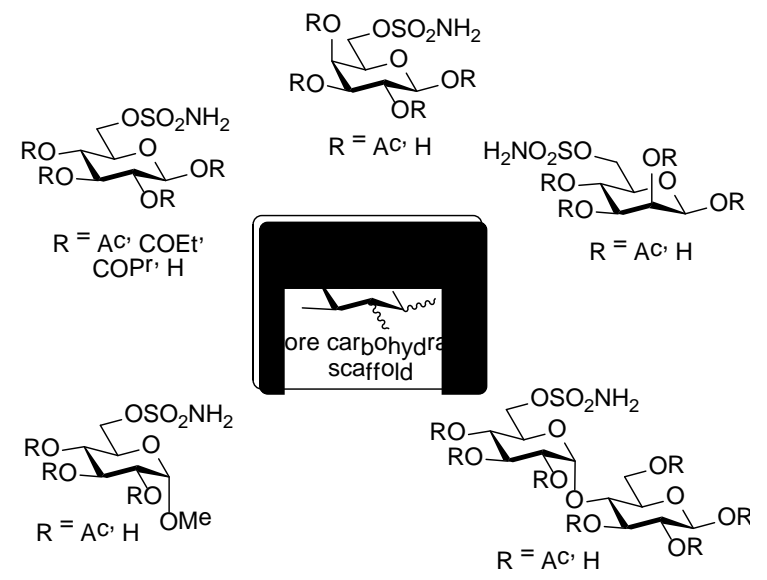

